\title{
Funkcja 1Hen 9,1-3 w strukturze literackiej mitu o upadłych aniołach 1Hen 6-11
}

\author{
The Function of 1 En. 9:1-3 in the Literary Structure \\ of the Myth of the Fallen Watchers (1 Enoch 6-11)
}

\author{
NATALIA DOMKA \\ Instytut Nauk Biblijnych, Katolicki Uniwersytet Lubelski Jana Pawła II \\ e-mail: natalia.domka@onet.pl \\ ORCID: 0000-0002-4469-6156
}

\begin{abstract}
The article analyzes the structure of 1 En. 9:1-3 and its function within the larger structure of the myth of the fallen Watchers (1 En. 6-11). The short text introduces the four angels on the scene, their perception of the miserable state of humanity, and the reception of human complaint directed to God. The positive presentation of the four angels can be contrasted by the negative presentation of the fallen Watchers in 1 En. 6:2-3.7-8. On the other hand, 1 En. 9:1-3 is related to 1 En. 10:1-16 where the same four angels receive from God the divine commissioning. Since it introduces the decisive turn in the myth narrative thread, 1 En. 9:1-3 divides the myth into two parts, which implies the symmetric disposition of the myth.
\end{abstract}

KeYwords: 1 En 9,1-3, 1 En 6-11, 1 Enoch, Book of the Watchers, myth of the fallen angels, literary structure of 1 En 6-11

SŁowa KLuCze: 1Hen 9,1-3, 1Hen 6-11, 1 Henoch, Księga Czuwających, mit o upadłych aniołach, struktura 1 Hen $6-11$

\section{Wprowadzenie}

Z

najdujący się w Pierwszej Księdze Henocha Mit o upadtych aniołach (1Hen 6-11) jest jednym z najstarszych tekstów literatury apokaliptycznej wczesnego judaizmu. Jakkolwiek wywarł on olbrzymi wpływ na rozwój tradycji apokaliptycznej w starożytnym Izraelu, to jego rozumienie i interpretacja różnią się $\mathrm{w}$ analizach egzegetów, którzy przypisują owym sześciu rozdziałom różne znaczenia ${ }^{1}$.

1 Tekst 1Hen 6-11 należy do Księgi Czuwających (1Hen 1-36 lub 1Hen 6-36), uważanej przez większość egzegetów za reinterpretację Księgi Rodzaju. Inną opinię prezentuje H.S. Kvanvig. Twierdzi on, iż tradycje - henochicka i biblijna - to dwie niezależne od siebie interpretacje mezopotamskich opowiadań dotyczących początku stworzenia (zob. H.S. Kvanvig, „The Watcher Story and Genesis. Intertextual Reading”, Scandinavian Journal of the Old Testament 18/2 [2008] 163-183). Inna grupa egzegetów przypisuje sekcji 1Hen 6-11 szczególne znaczenie 
Celem niniejszego artykułu jest próba odpowiedzi na pytanie, jaką funkcję w strukturze mitu o upadłych aniołach pełni tekst 1Hen 9,1-3. Fragment ten wydaje się stanowić bowiem ważny punkt w narracji 1Hen 6-11. Poprzedza go relacja o buncie aniołów, polegającym na ich zstąpieniu na ziemię w celu połączenia się z kobietami (1Hen 6,1-7,1a). Ze związków tych zrodzili się giganci (demoniczni wojownicy), którzy niszczą ziemię (1Hen 7,2-5). Ponadto rozdziały 7-8, poprzedzające 1Hen 9,1-3, zawierają również opis działalności dydaktycznej aniołów Czuwających. Rozpowszechniają oni wiedzę tajemną (1Hen 7,1b; 1Hen 8,1-3), przez co sprowadzają na ludzi wielkie cierpienie oraz czynią ich całkowicie bezradnymi wobec przemocy i zła, które zaistniało na ziemi (1Hen 7,6; 1Hen 8,4). Po fragmencie 1Hen 9,1-3 sytuacja ta stopniowo zmienia się. Narracja podąża w kierunku rozwiązania komplikacji linii narracyjnej poprzez wstawiennictwo czterech wielkich archaniołów (1Hen 9,4-11), ich rozesłanie przez Boga (1Hen 10,1-16a) oraz mowę końcową Najwyższego (1Hen 10,16b-11,2). Wielu autorów odnotowało przywołane wyżej główne elementy fabuły 1Hen 6-11, jednakże żaden z nich nie wyjaśnił zabiegu literackiego polegającego na przejściu od sytuacji problemowej w 1 Hen $6-8$ do sceny końcowej mitu. Nie zauważono również, iż przełomowy moment tego procesu następuje w 1Hen 9,1-3.

\section{Dotychczasowe opinie}

Według G.W.E. Nickelsburga wiersze 1Hen 9,1-3 stanowią przede wszystkim część anielskiej odpowiedzi na zarzuty postawione Czuwającym². Egzegeta, dzieląc sekcję 1Hen 9,1-11 na dwa elementy, jako pierwszy wymienia interesu-

dla samej Pierwszej Księgi Henocha. Według R.A. Argalla stanowi ona część Testamentu Henocha, w którym pełni rolę tła dla elementów biograficznych w dalszych rozdziałach Księgi Czuwających (zob. R.A. Argall, 1 Enoch and Sirach. A Comparative Literary and Conceptual Analysis of the Themes of Revelation, Creation and Judgment [Society of Biblical Literature. Early Judaism and Its Literature 8; Atlanta, GA: Scholars Press 1995] 24). Z kolei M. Black uważa owe sześć rozdziałów za istotne wprowadzenie do Księgi Henocha, będące częścią 1Hen 6-16 - Legendy Czuwających (zob. M. Black, The Book of Enoch or I Enoch. A New English Edition with Commentary and Textual Notes [Studia in Veteris Testamenti Pseudepigrapha 7; Leiden: Brill 1985] 13-15). Natomiast D. Iwański przytacza koncepcję, w świetle której tekst 1Hen 6-11 stanowi punkt odniesienia dla rozdziałów 1Hen 12-16, będących jego reinterpretacją (zob. D. Iwański, Wstawiennictwo aniołów w Księdze Henocha (1Hen) [Scripta Theologica Thoruniensia 15; Toruń: Wydawnictwo Naukowe UMK, 2011] 62).

2 Przeprowadzając refleksję nad tradycjami obecnymi w micie, Nickelsburg podzielił tekst na sześć części oraz wyróżnił w nich jeszcze mniejsze jednostki tematyczne. Według niego do sześciu wiodących części należą następujące fragmenty: spisek aniołów (1Hen 6,1-8), ich czyn (1Hen 7,1), jego skutki (1Hen 7,2-5), zarzut postawiony Asaelowi i innym aniołom (1Hen 7,6-8,4), odpowiedź aniołów (1Hen 9,1-11), odpowiedź Boga (1Hen 10,1-11,2). Zob. G.W.E. Nickelsburg, 1 Enoch 1. A Commentary of the Book of 1 Enoch, Chapters 1-36; 81-108 (Hermeneia; Minneapolis, MN: Fortress Press 2001) 165-173. Analiza struktury 1Hen 6-11 wraz z komentarzem znajduje się 
jący nas fragment 1Hen 9,1-3, podkreślając w nim postawę aniołów ${ }^{3}$. Ponadto zauważa, iż działalność anielska w 1 Hen 9 składa się z trzech etapów. Aniołowie są mediatorami, orędownikami i prawnymi przeciwnikami. W opinii autora wersety 1Hen 9,1-3 wskazują na pierwszą funkcję aniołów: są świadkami przemocy na ziemi $(1 \mathrm{Hen} 9,1)$ oraz wkraczają do nieba, rozmawiając o tym, co widzieli (1Hen 9,2-3) .

H. Drawnel również rozpatruje 1 Hen 9,1-11 jako jeden blok ${ }^{5}$. W wierszach 1Hen 9,1-3 zaznacza trzy ważne momenty: patrzenie z niebiańskiej świątyni (1Hen 9,1), wejście do niej (1Hen 9,2) i wzywanie pomocy przez ludzkość (1Hen 9,3). W świetle tej koncepcji szczególną rolę zdaje się spełniać werset ostatni, który stanowi powtórzenie wcześniejszego apelu (zob. 1Hen 8,4), wprowadza powód anielskiej interwencji (zob. 1Hen 9,4-11) oraz nadaje perykopie kontekst prawny (zob. 1Hen 9,10) .

Do grupy komentatorów traktujących 1Hen 9,1-3 w łączności z 1Hen 9,4-11 należy także C. Molenberg. W jego propozycji struktury opowiadania o interwencji aniołów, fragment 1 Hen 9,1-3 jawi się jako opis kondycji ludzkości . Autor wykazuje to w podziale wierszy na: krew widzianą na ziemi $(1 \mathrm{Hen} 9,1)$ oraz wołanie o pomoc $(1 \mathrm{Hen} 9,2-3)^{8}$.

Inne stanowisko reprezentuje P.D. Hanson, który tekst 1Hen 9,1-3 omawia w ramach 1Hen 9,1-10,15 (wyłączając wersety 1Hen 9,6.8c; 1Hen 10,4-10).

również w: G.W.E. Nickelsburg, „Apocalyptic and Myth in 1 Enoch 6-11”, Journal of Biblical Literature 96/3 (1977) 383-405.

3 Prezentując ogólną strukturę 1Hen 6-11, Nickelsburg podkreśla wysłuchanie przez aniołów skargi ludzkości, natomiast w szczegółowym komentarzu do 1Hen 9,1-3 wiele uwagi poświęca ich oglądowi sytuacji na ziemi. Zob. Nickelsburg, 1 Enoch 1. A Commentary, 165, 206-207; Nickelsburg, „Apocalyptic and Myth”, 384.

4 Zob. Nickelsburg, 1 Enoch 1. A Commentary, 207.

5 Drawnel analizuje treść opowiadania o upadłych aniołach w kontekście literatury mezopotamskiej. W wyniku przeprowadzonych badań zauważa cztery etapy tej historii, przypisując jej elementy schematu zaklęcia egzorcystycznego Marduk-Ea. Podaje następujące elementy mitu: wprowadzenie $(6,1-8,4)$, reakcja aniołów i relacja do Boga (9,1-11), boska instrukcja (10,1-14), błogosławiona przyszłość bez nieczystości $(10,15-11,2)$. Zob. H. Drawnel, „1 Enoch 6-11 Interpreted in the Light of Mesopotamian Incantation Literature", Enoch and the Synoptic Gospels. Reminiscences, Allusions, Intertextuality (ed. L.T. Stuckenbruck - G. Boccaccini) (Society of Biblical Literature Early Judaism and Its Literature 44; Atlanta, GA: SBL Press 2016) 256, 258-275.

6 Zob. Drawnel, „1 Enoch 6-11 Interpreted”, 262. Ostatni werset stanowi ponadto formę raportu z oskarżenia wniesionego przez umierającą ludzkość, który nie odnajduje swego odpowiednika w schemacie Marduk-Ea. Dwa wcześniejsze wiersze są natomiast podobne do opisu momentu, kiedy Marduk zauważa problem, o którym potem rozmawia z bogiem Ea. Zob. Drawnel, „1 Enoch 6-11 Interpreted", 282-283.

7 W swej analizie Molenberg wyróżnia trzy główne bloki tematyczne w strukturze mitu: pochodzenie cierpienia na ziemi (1Hen 6,1-8,4), interwencję aniołów (1Hen 9,1-11) oraz Boże instrukcje dla archaniołów (1Hen 10,1-11,2). W każdej z tych części zauważa ponadto mniejsze sekcje, które mają odzwierciedlać relacje między historią Szemichazy i Asaela. Zob. C. Molenberg, „A Study of the Roles of Shemihaza and Asael in I Enoch 6-11", Journal of Jewish Studies 35 (1984) 136-137.

8 Zob. Molenberg, „A Study of the Roles”, 137. 
Traktuje go przede wszystkim jako kolejną parafrazę Księgi Rodzaju zawartą w micie ${ }^{9}$. Zauważa, że reakcje aniołów w 1 Hen 9,1 są paralelne do czynności

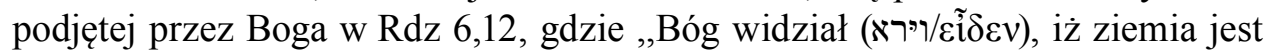
skażona, że wszyscy ludzie postępują na ziemi niegodziwie". Zabieg ten uzasadnia ideą deantropomorfizacji Boga, obecną w literaturze okresu Drugiej Świątyni, a która odnajduje tutaj swoje odzwierciedlenie ${ }^{10}$.

Przywołane wyżej teorie nie wskazują jednoznacznie, jaką funkcję w strukturze mitu spełnia tekst 1Hen 9,1-3. Najbardziej popularnym podejściem zdaje się być łączenie tych wierszy z modlitwą wstawienniczą aniołów i traktowanie ich jako formy wprowadzenia do niej (Nickelsburg, Drawnel, Molenberg). Jednakże jego znaczenie można rozumieć w różny sposób. Istnieje także możliwość odczytywania wersetów 1Hen 9,1-3 w świetle literatury pozahenochicznej (Hanson). Rozwiązania tego typu nie są jednak doskonałe, ponieważ nie rozstrzygają ostatecznie problemu dotyczącego zależności poszczególnych elementów 1Hen 6-11 od innych tradycji.

Zauważone wyżej trudności w określeniu roli 1Hen 9,1-3 w 1Hen 6-11 oraz niedobór komentarzy uwzględniających relacje między poszczególnymi elementami mitu dają podstawę, aby spojrzeć na ten problem z punktu widzenia synchronicznego, badając kompozycję oraz treść 1Hen 9,1-3 (część 1, §2) i osadzając ją w strukturze całego opowiadania 1Hen 6-11 (część 2, §3).

\section{Kompozycja i treść 1Hen 9,1-3}

Poniżej zostanie omówiony zakres i kontekst badanego tekstu (§2.1), przebieg narracji (\$2.2), wewnętrzny podział (\$2.3) oraz wynikająca z niego struktura 1Hen 9,1-3 (\$2.4). Analizy te w sposób szczególny dotyczyć będą podobieństw

9 Według Hansona cztery główne części mitu poprzedzone są wersetami 1Hen 6,1-2a, które stanowią tło dla historii z Rdz. Potem następuje: opis buntu i pochodzenia istot nadprzyrodzonych (1Hen 6,2b-8); współżycie z kobietami, narodziny gigantów, ich destrukcyjna działalność, skarga ziemi (1Hen 7,1-6; 8,4); anielskie wstawiennictwo przed Najwyższym, uwolnienie Noego, kara dla winowajców i ich potomstwa - związanie i wrzucenie w ognistą otchłań (1Hen 9,1-10,15); przywrócenie królestwa Najwyższego i kosmicznego porządku (1Hen 10,16-11,2). Zob. P.D. Hanson, „Rebellion in Heaven, Azazel, and Euhemeristic Heroes in 1 Enoch 6-11”, Journal of Biblical Literature 96 (1977) 197-202, 204.

10 W scenie wstawiennictwa aniołów autor podkreśla również zabieg amplifikacji, nacisk na wszechwiedzę Najwyższego oraz rolę hymnicznego wprowadzenia - charakterystycznego dla literatury miedzytestamentalnej. Tekst 1Hen 9,1-3 łączy z fragmentem 1Hen 10,1-4, w którym widzi kolejną parafrazę dotyczącą tym razem początku biblijnej historii ocalenia Noego - Rdz 6,13. Obecne tutaj związki z Księgą Rodzaju, według Hansona, są trzecim etapem cyklu reinterpretacji obecnych w micie. Poprzednie dotyczyły relacji między 1 Hen $6,2 \mathrm{~b}-8$ i Rdz $6,2 \mathrm{~b}$ oraz 1 Hen 7,1 6; 8,4 i Rdz 4,10; 6,2b.4-12; 8,2; 9,4. Ostatnia część mitu (1Hen 10,16-11,2) miałaby natomiast nawiązywać do Rdz 9,8-17. Zob. Hanson, „Rebellion in Heaven”, 200-201. 
i różnic występujących między trzema wariantami tekstu greckiego poświadczonego w kodeksie Panopolitanus $\left(\mathrm{G}^{\mathrm{C}-1}\right)$ oraz w dwóch fragmentach z chronografii Syncellusa $\left(\mathrm{G}^{\mathrm{S}-1} ; \mathrm{G}^{\mathrm{S}-2}\right)^{11}$.

\subsection{Określenie zakresu i kontekstu tekstu}

Na granice sekcji 1Hen 9,1-3 wskazuje kilka zmian językowych i tematycznych. Po pierwsze, zmienia się główny temat opowiadania. Kontekst poprzedzający, jakim jest fragment dotyczący działalności dydaktycznej Asaela i innych Czuwających (1Hen 8,1-3), zdaje się nie dotyczyć bezpośrednio tematyki obecnej w 1Hen 9,1-3. Kończąca go informacja o krzyku ginących ludzi, który wzniósł się do nieba $(1$ Hen 8,4$)$ nie tylko wprowadza nowy temat, lecz służy również połączeniu poprzedniej perykopy z 1 Hen $9,1-3^{12}$. Pozwala także wprowadzić na scenę wydarzeń nowych bohaterów: Michała, Uriela, Rafała i Gabriela (1Hen 9,1) ${ }^{13}$, co jest kolejnym ważnym punktem zwrotnym w opowiadaniu. Werset 1 Hen 8,4

11 Teksty te odzwierciedlają oryginał aramejski. Wśród siedmiu kopii aramejskich wersji Księgi Henocha znalezionych w czwartej grocie w Qumran znajdują się dwie - 4Q201 fr.1 iv 6-10 oraz 4Q202 fr.1 iii 7-11 - które zawierają interesujący nas tekst 1Hen 9,1-3. Zachował się on również w języku etiopskim ( $\left.g \partial{ }^{\prime} \partial z\right)$. W niniejszym artykule analizy tekstów greckich zostały przeprowadzone na podstawie dwóch publikacji. W przypadku kodeksu Panopolitanus skorzystano z: M. Black, Apocalypsis Henochi Graece (Pseudepigrapha Veteris Testamenti Graece 3; Leiden: Brill 1970). Natomiast fragmenty z kroniki Syncellusa pochodzą z: A.A. Mosshammer, Georgii Sincelli Ecloga Chronographica (Leipzig: Teubner Verlagsgesellschaft 1984). W sytuacji aramejskich wersji tekstu posłużono się wydaniem krytycznym: H. Drawnel, Qumran Cave 4: The Aramaic Books of Enoch (Oxford: Oxford University Press [w druku]) w konsultacji ze starszym wydaniem: J.T Milik, The Books of Enoch: Aramaic Fragments of Qumran Cave 4 (Oxford: Clarendon Press 1976). Uwagi na temat etiopskiego thumaczenia odnoszą się do: R.H. Charles, The Ethiopic Version of the Book of Enoch (Oxford, MS: Clarendon Press 1906; repr. Collingwood, Vic.: Trieste 2017).

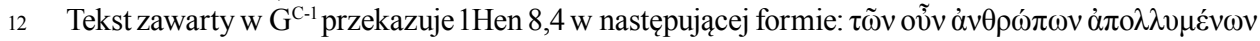

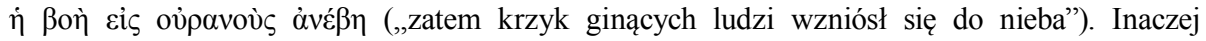

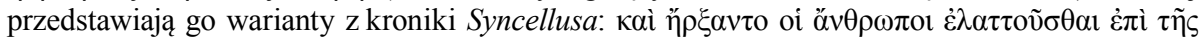

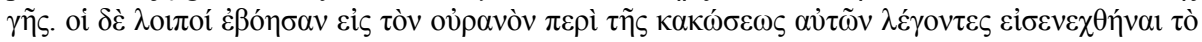

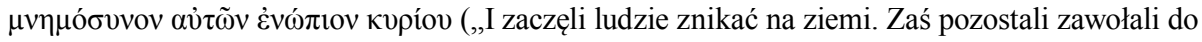
nieba o ucisku swym mówiąc, aby została zaniesiona pamięć o nich przed Pana", za $\left.\mathrm{G}^{\mathrm{S}-1}\right)$; $\tau$ ó $\varepsilon$

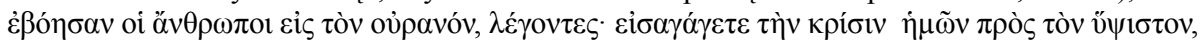

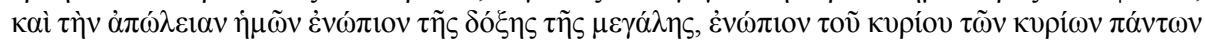
$\tau \tilde{n} \mu \varepsilon \gamma \alpha \lambda \omega \sigma u ́ v \eta ̣$ (,wówczas zawołali ludzie do nieba mówiąc: zanieście skargę naszą przed Najwyższego i naszą zagładę przed Chwałę Wielką przed Pana wszystkich panów w Majestacie", ולקבל מבד ק[צת אנשא] מן ארעא

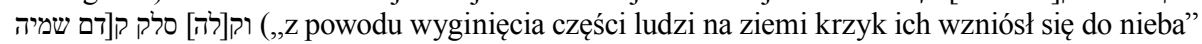

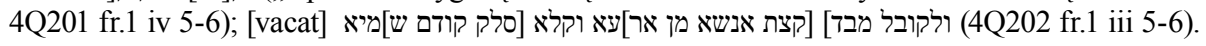
Zob. Milik, The Books of Enoch, 157, 170.

13 Jest to lista aniołów według tekstów greckich i tłumaczenia etiopskiego. We fragmencie aramejskim 4Q201 fr.1 iv 6 zachowały się imiona dwóch aniołów: Michała i Rafała. Na podstawie fragmentu 4Q202 fr.1 iii 7 można zrekonstruować imiona dwóch pozostałych: Sariela i Gabriela. Teksty 
przekazuje powód, dla którego czterej archaniołowie podejmują w 1Hen 9,1-2

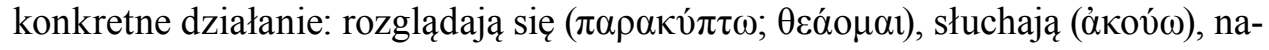
radzają się ( $\lambda \dot{\varepsilon} \gamma \omega \pi \rho o ̀ \varsigma ~ \dot{\alpha} \lambda \lambda \eta ́ \hat{\lambda o v \varsigma) ~ o r a z, ~ w ~ d a l s z e j ~ c z e ̨ s ́ c i ~ n a r r a c j i ~(1 H e n ~ 9,4-11), ~}$ modlą się wstawienniczo.

Trzecim elementem odróżniającym interesujący nas tekst od wcześniejszych zdarzeń jest zmiana miejsca wydarzeń. Można przypuszczać, że początek mitu sugeruje obecność Czuwających w sferze niebieskiej. W 1Hen 6,2 nazwani zo-

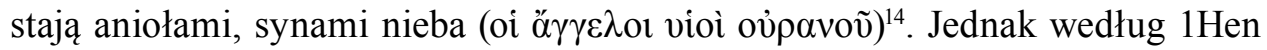
6,5-8,4 przebywają przede wszystkim na ziemi i tam prowadzą swoją destrukcyjną działalność. Od 1Hen 9,1 miejscem narracji jest natomiast sanktuarium

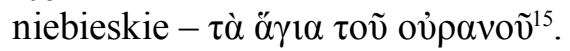

Poza tym - według $\mathrm{G}^{\mathrm{C}-1}$ - tekst grecki w 1 Hen 9,1 zaznacza nowy etap rozwoju narracji poprzez użycie partykuły $\tau$ ó $\tau \varepsilon^{16}$. Inaczej dzieje się $w \mathrm{G}^{\mathrm{S}-1}, \mathrm{G}^{\mathrm{S}-2}$, gdzie rozpoczynający sekcję spójnik кaì wskazuje na ciągłość narracyjną z kontekstem wcześniejszym. Należy też zauważyć, że po wersecie końcowym $(1$ Hen 9,3$)$ oraz doksologii (1Hen 9,4-5) rozpoczyna się narracja metadiegetyczna (wcześniejsze zdarzenia opowiedziane z punktu widzenia bohaterów opowiadania) ${ }^{17}$, która trwa aż do 1 Hen 9,11.

Począwszy od 1Hen 9,4 aniołowie podejmują modlitwę, która w swej pierwszej i końcowej części skupiona jest na Bogu i Jego przymiotach (1Hen 9,4-5.11) ${ }^{18}$.

greckie i etiopski pomijają Sariela, zamiast którego występuje Uriel. Zob. Charles, The Ethiopic Version, 18-20; Milik, The Books of Enoch, 157, 170.

14 Według $\mathrm{G}^{\mathrm{C}-1}$. Werset zachował się również $\mathrm{w} \mathrm{G}^{\mathrm{S}-1}$, gdzie w miejscu oi ö $\gamma \gamma \varepsilon \lambda$ or vioì oủ $\alpha$ voṽ

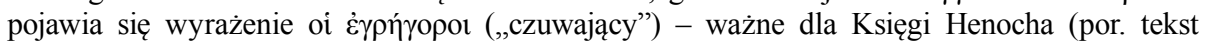
grecki 1 Hen 1,5; 6,2; 10,7.9.15; 12,2-4; 13,10; 14,1.3; 15,9; 16,2). Zob. A.M. Denis, Concordance grecque des Pseudépigraphes d'Ancien Testament (Louvain: Peeters 1987) 289-290. Jest to termin odpowiadający aramejskiemu słowu ע, obecnemu w 4Q202 fr.1 ii 3 (por. tekst aramejski Księgi Czuwających: 1Hen 10, 7.9; 12,2.3; 13,10; 14,1.3; 15,2.9; 16,1.2; 22,6). Zob. Milik, The Books of Enoch, 165; M.G. Abegg, The Dead Sea Scrolls Concordance. Vol. 1: The Non-Biblical Texts from Qumran (Leiden: Brill 2003) II, 896. Na temat tego terminu w tekstach biblijnych i Corpus Henochicum zob. Iwański, Wstawiennictwo aniołów, 46-47, 86-88.

15 Według tekstu $\mathrm{G}^{\mathrm{S}-1}, \mathrm{G}^{\mathrm{S}-2}$, pokrywającego się częściowo z 4Q201 fr.1 iv 7: מן קדש]' שמיה (,z sanktuarium nieba"). Tekst etiopski jest zgodny z thumaczeniem $\mathrm{G}^{\mathrm{C}-1}$. Zob. Charles, The Ethiopic Version, 18-20; Milik, The Books of Enoch, 157.

16 recki termin $\tau$ ó $\tau \varepsilon$ („wtedy”, „potem”) odpowiada aramejskiemu słowu אדין, obecnemu w rekonstrukcjach 4Q201 fr.1 iv 6; 4Q202 fr.1 iii 7. Zob. Milik, The Books of Enoch, 157. Zarówno termin grecki, jak i aramejski podkreślają nowy etap narracji. Zob. E.M. Cook, Dictionary of Qumran Aramaic (Winona Lake, IN: Eisenbrauns 2015) 3; T. Muraoka, A Greek-English Lexicon of the Septuagint (Louvain: Peeters 2009) 685; T. Muraoka, A Greek-Hebrew/Aramaic Two-way Index to the Septuagint (Louvain: Peeters 2010) 118-119.

17 Jest to tzw. druga instancja narracyjna. Aniołowie zostają przedstawieni jako opowiadający (intradiegetic) oraz przedstawiają swój punkt widzenia, przez co nadają określony kierunek opowiadaniu. Zob. S. Szymik, Współczesne modele egzegezy biblijnej (Lublin: Wydawnictwo KUL 2013) 76-77.

18 Na temat struktury modlitwy 1 Hen 9,4-11 zob. M.J. Davidson, Angels at Qumran. A Comparative Study of 1 Enoch 1-36, 72-108 and Sectarian Writings from Qumran (Journal for the Study of the 
Dopiero później zostają przywołane szczegóły dotyczące destrukcyjnej działalności Czuwających i gigantów (1Hen 9,6-9) wraz z fragmentem 1Hen 9,10 bezpośrednio nawiązującym do 1 Hen $9,1-3^{19}$.

Powyższe obserwacje pozwalają stwierdzić, iż zmiany umożliwiające wyróżnienie tekstu 1Hen 9,1-3 jako osobnej jednostki literackiej dotyczą trzech obszarów: (1) relacji do poprzedniej perykopy (1Hen 8,1-4); (2) kontekstu dalszej narracji (1Hen 9,4-11); (3) sposobu prowadzenia dyskursu. Jednocześnie trzeba zaznaczyć, że wokół tych trzech elementów pojawiają się sygnały, dzięki którym wiersze 1Hen 9,1-3 pozostają w łączności z innymi częściami mitu. Na tym etapie analizy taką rolę można przypisać szczególnie fragmentom 1 Hen 8,4 oraz 1 Hen 9,10, które wykazują terminologiczne i tematyczne powiązanie z 1Hen 9,1-3.

\subsection{Przebieg narracji 1 Hen $9,1-3$}

\section{a) 1 Hen 9,1}

Pierwszy z wersetów będących przedmiotem naszych zainteresowań opowiada o reakcji aniołów na krzyk ginących ludzi (zob. 1Hen 8,4). Nowi bohaterowie mitu słyszą go oraz przyglądają się dramatycznej sytuacji zaistniałej na ziemi. Redaktorzy przedstawili ten epizod na różne sposoby, co ukazuje poniższa tabela ${ }^{20}$.

Pseudepigrapha. Supplement Series 11; Sheffield: A\&C Black 1992) 49; J.P. Sisson, „Intercession and the Denial of Peace in 1 Enoch 12-16", Hebrew Annual Review 11 (1987) 377.

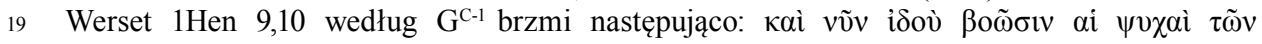

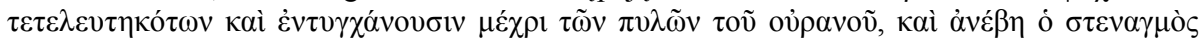

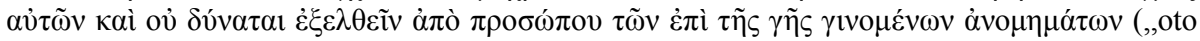
teraz wołają dusze zmarłych i wzdychają aż do bram nieba i została wzniesiona skarga ich i nie może odejść od oblicza zaistniałej nieprawości na ziemi”). Świadectwo G ${ }^{\mathrm{S}-2}$ zachowuje

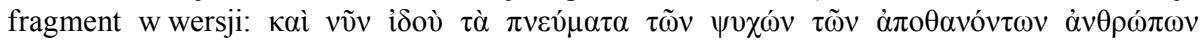

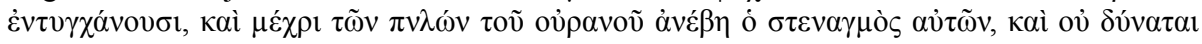

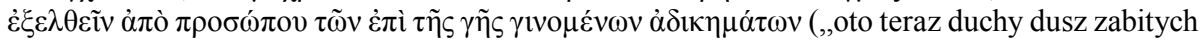
ludzi wzdychają i aż do bram nieba została wzniesiona ich skarga i nie może odejść od oblicza zaistniałej niesprawiedliwości na ziemi”). Tekst aramejski nie zachował się. Na temat krytyki tego tekstu zob. R.H. Charles, The Book of Enoch or 1 Enoch. Translated from the Editor's Ethiopic Text (Oxford, MS: Oxford University Press 1912; repr. Eugene, OR: Wipf and Stock 2011) 21-22; Nickelsburg, 1 Enoch 1. A Commentary, 205.

20 Zob. Black, Apocalypsis Henochi Graece, 23; Mosshammer, Georgii Sincelli, 13, 24. 
Tabela 1. Greckie tłumaczenia 1Hen 9,1

\begin{tabular}{|c|c|c|}
\hline Panopolitanus $\left(\mathrm{G}^{\mathrm{C}-1}\right)$ & Syncellus $\left(\mathrm{G}^{\mathrm{S}-1}\right)$ & Syncellus $\left(\mathrm{G}^{\mathrm{S}-2}\right)$ \\
\hline 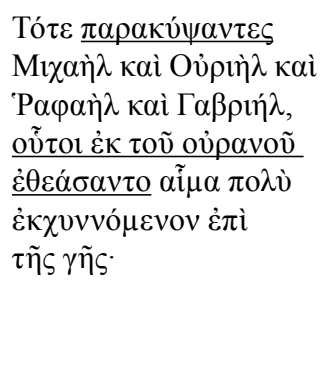 & 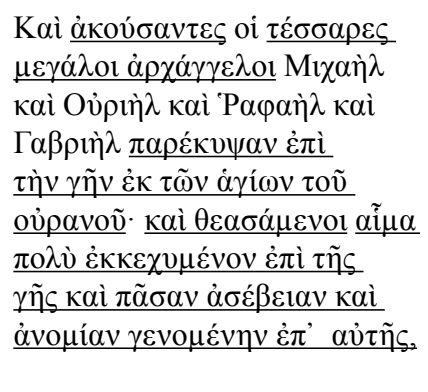 & 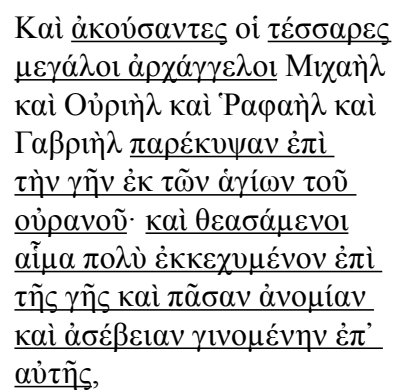 \\
\hline
\end{tabular}

Jak już wyżej zauważono, między $\mathrm{G}^{\mathrm{C}-1}$ a świadectwami $\mathrm{G}^{\mathrm{S}-1}$ i $\mathrm{G}^{\mathrm{S}-2}$ występuje różnica $\mathrm{W}$ sposobie rozpoczęcia nowego etapu narracji. Po partykule $\tau o ́ \tau \varepsilon\left(\mathrm{G}^{\mathrm{C}-1}\right)$ lub spójniku кai $\left(\mathrm{G}^{\mathrm{S}-1}, \mathrm{G}^{\mathrm{S}-2}\right)$ pojawia się opis czynności podjętych przez Michała, Uriela, Rafała i Gabriela. W kodeksie Panopolitanus aniołowie spojrzeli na dół, pochylili się (dosł. „spojrzawszy na dół, pochyliwszy się” - $\pi \alpha \rho \alpha \kappa v ́ \psi \alpha \nu \tau \varepsilon \varsigma)^{21}$. Następnie zostaje wyraźnie zaznaczone przez zaimek wskazujący, iż to właśnie „oni zobaczyli” (oṽ̃ol $\dot{\varepsilon} \theta \varepsilon \alpha ́ \sigma \alpha \nu \tau o)^{22}$ to, co dzieje się na ziemi. Natomiast warian-

21 Czasownik $\pi \alpha \rho \alpha \kappa v ́ \pi \tau \omega$ posiada przynamniej dwa główne aspekty znaczeniowe. Pierwszy dotyczy patrzenia jako czynności „pochylenia się, aby zobaczyć” (por. Łk 24,12; J 20,5.11; Prz 7,6; Syr 21,23). Drugi kierunek wyjaśnienia tego czasownika związany jest z czynnością intelektualną „wejrzenia w” (por. Jk 1,25; 1P 1,12). W pierwszym wymiarze patrzenie miałoby być motywowane ciekawością i chęcią dotarcia wzrokiem do czegoś, czego się nie widzi. Natomiast celem oglądania czegoś umysłem jest osiągnięcie zrozumienia jakiejś sprawy, rzeczy, rozważania, medytacji, zdobycia wiedzy w jakimś zakresie. Por. F.W. Danker, A Greek-English Lexicon of the New Testament and other Early Christian Literature (Chicago-London: The University of Chicago Press 2000) 767. Z punktu widzenia literatury klasycznej czasownik ten, poza wymienionymi wyżej znaczeniami, można tłumaczyć również jako „wypatrywanie kogoś” (z accusativem), ,przedostać się do czegoś”, „zgiąć się, schylać się na bok”, „rzucić okiem”. Zob. O. Jurewicz, Stownik greckopolski (Warszawa: Wydawnictwo Naukowe SUB LUPA 2015) 722. Aramejskie fragmenty odnotowują w jego miejscu czasownik דוק, który w koniugacji 'af 'el oznacza „wyglądać, wyjrzeć”. Zob. Cook, Dictionary, 51. Pojawienie się go w liczbie pojedynczej w 1Hen 9,1 (אדיק) być może jest spowodowane faktem, iż czasownik ten łączy się bezpośrednio z osobą Michała, a autor mógł nie wiedzieć, czy po nim pojawią się jeszcze inne podmioty czynności. Zob. T. Muraoka, A Grammar of Qumran Aramaic (Ancient Near Eastern Studies 38; Leuven: Peeters 2011) 230. Inne wyjaśnienie mówi o tym, że termin ten występuje na początku zdania, podobnie jak w składni hebrajskiej. Zob. P. Joüon - T. Muraoka, A Grammar of Biblical Hebrew (Subsidia Biblica 14; Roma: Editrice Pontificio Instituto Biblico 1991) II, 549-557.

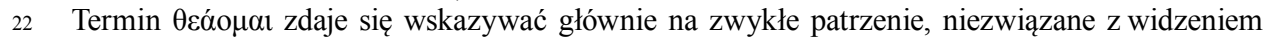
nadnaturalnym. W takim znaczeniu występuje w większości świadectw biblijnych (np. Mt 11,17; Łk 7,24; J 1,38). Niektóre teksty sugerują jednak głębszy sens tego terminu, ponieważ dotyczą oglądania Bożych dzieł (np. Jdt 15,8; Tb 13,7; Dz 1,11). Zob. Danker, A Greek-English Lexicon, 445-446. W literaturze klasycznej czasownik ten występuje także jako patrzenie, rozglądanie się $\mathrm{z}$ podziwem, rozważanie w sobie, bycie widzem w teatrze ( $\mathrm{w}$ formie participium), dokonywanie 
ty z kroniki Syncellusa przekazują następującą kolejność anielskiego działania:

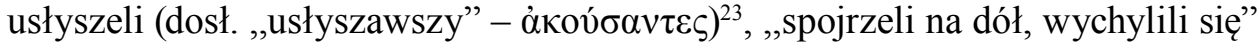
$(\pi \alpha \rho \varepsilon ́ \kappa v \psi \alpha v)$ i zobaczyli (dosł. ,zobaczywszy”- $-\theta \varepsilon \alpha \sigma \alpha ́ \mu \varepsilon v o$ ), pomijając zaimek, jednakże wcześniej przypisują owe czynności czterem wielkim archaniołom (oi $\tau \dot{\varepsilon} \sigma \sigma \alpha \rho \varepsilon \varsigma \mu \varepsilon \gamma \alpha \dot{\lambda}$ ol $\dot{\alpha} \rho \chi \alpha ́ \gamma \gamma \varepsilon \lambda \mathrm{ol})^{24}$, o czym nie mówi $\mathrm{G}^{\mathrm{C}-1}$.

We wszystkich manuskryptach można zauważyć, iż archaniołowie znajdują

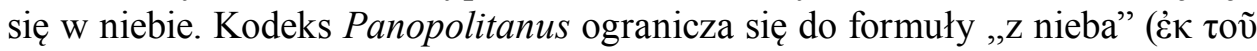

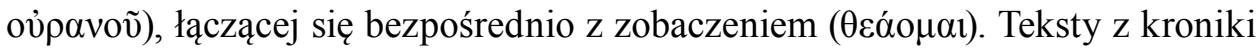
Syncellusa bardzo precyzyjnie opowiadają w tym punkcie o patrzeniu na dól

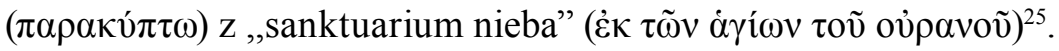

Każdy z przywołanych wariantów zawiera wyrażenie wskazujące na ziemię jako przedmiot oglądu. $\mathrm{W} \mathrm{G}^{\mathrm{C}-1}$ związane jest ono jedynie z przelaniem dużej

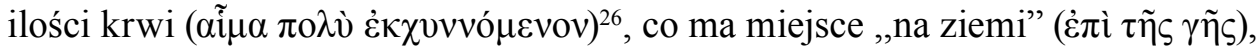
a w $\mathrm{G}^{\mathrm{S}-1} \mathrm{i} \mathrm{G}^{\mathrm{S}-2}$ łączy się również ze wspomnianym wyżej czasownikiem $\pi \alpha \rho \alpha \kappa v ́-$

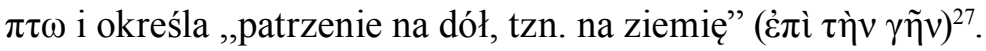

Przywołana już dramatyczna sytuacja na ziemi zostaje opisana szerzej w $\mathrm{G}^{\mathrm{S}-1}$ $i^{\mathrm{S}}{ }^{\mathrm{S}-2}$. Do obecnej również w $\mathrm{G}^{\mathrm{C}-1}$ informacji o dużej ilości rozlanej krwi, dodano

przeglądu wojska. Zob. Jurewicz, Stownik, 442. W miejscu tego terminu aramejski tekst 1Hen 9,1

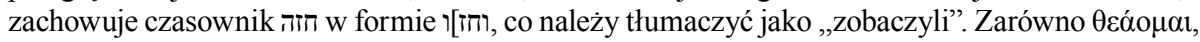
jak i חזה występują bardzo często w Księdze Henocha. Zob. Abegg, The Dead Sea Scrolls, 832-833; Denis, Concordance grecque, 401.

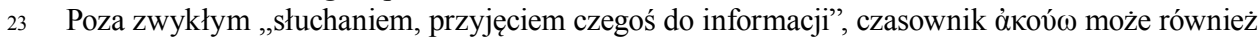
wyrażać „wysłuchanie skargi w sądzie” (por. J 7,51; Dz 25,22). Kontekst prawny wersetu 1Hen 9,1 pozwala przyjąć takie znaczenie tego terminu. Zob. Danker, A Greek-English Lexicon, 37-38.

24 Informacja o czterech aniołach odnotowana w $\mathrm{G}^{\mathrm{S}-1}, \mathrm{G}^{\mathrm{S}-2}$ wraz $\mathrm{z}$ opisem ich posłania w rozdziale 1 Hen 10 jest istotna dla problemów związanych zustaleniem ich liczby w 1Hen 9,4. Zob. Nickelsburg, 1 Enoch 1. A Commentary, 203.

25 Aramejskie wyrażenie מן קדש] שמיה (4Q201 fr.1 iv 7), מן קודשי שמיא (4Q202 fr.1 iii 7) odpowiada wersjom $\mathrm{G}^{\mathrm{S}-1}, \mathrm{G}^{\mathrm{S}-2}$. Egzegeci widzą w nim nie tylko zwykłe niebo jako miejsce przebywania Boga, ale także sanktuarium. Zob. Black, The Book of Enoch, 129. Interpretacja ta nadaje więc 1Hen 9,1 wymiar kultyczny, wskazując na miejsce przebywania aniołów i Boga. Więcej na temat tej koncepcji w Księdze Czuwających zob. D. Iwański, „Mieszkanie Boga w niebie według Księgi Czuwających (1 Henoch 14,8-23)”, Collectanea Theologica 79/2 (2009) 101-112; Iwański, Wstawiennictwo aniotów, 112, 143-148.

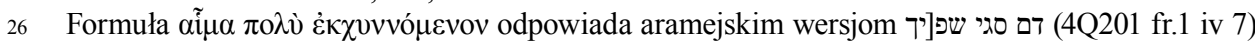

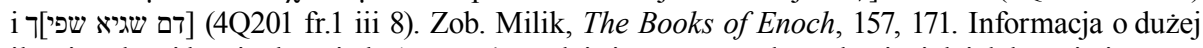
ilości rozlanej krwi odpowiada 1Hen 7,4-5, gdzie jest mowa o destrukcyjnej działalności gigantów

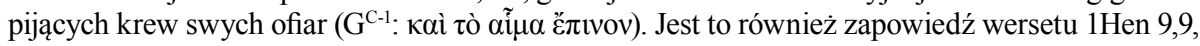

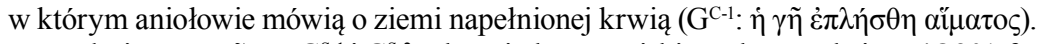

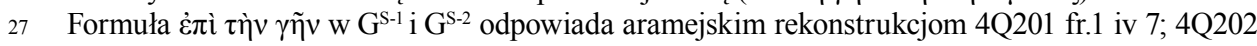
fr.1 iii 7, w których wyrażenie על ארעא (,na ziemię”) łączone jest zarówno z patrzeniem, jak

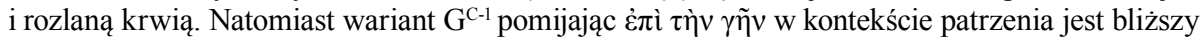
tłumaczeniu etiopskiemu, które również nie podaje tej informacji. Zob. Charles, The Ethiopic Version, 20; Milik, The Books of Enoch, 157, 171. 


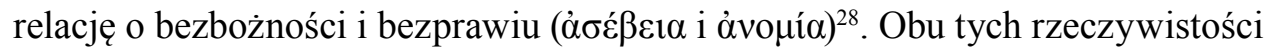

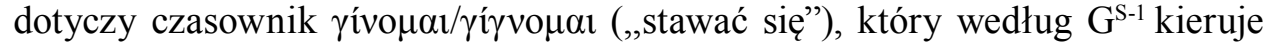
czytelnika mitu ku destrukcyjnym zdarzeniom, które już miały miejsce (participium aoristi: $\gamma \varepsilon v o \mu \varepsilon ́ v \eta \eta$ ), a w $\mathrm{G}^{\mathrm{S}-2}$ podkreśla wymiar przemocy, która jeszcze się dokonuje (participium praesentis: $\gamma(v o \mu \varepsilon ́ v \eta v)$. Po tej adnotacji pojawia się określenie „na niej” ( $\dot{\varepsilon} \pi$ ' $\alpha$ $\tau \tilde{\eta} \varsigma$ ), które wskazuje jednoznacznie na znaną z wcześniejszego kontekstu ziemię i zamyka werset 1 Hen $9,1^{29}$.

\section{b) 1 Hen 9,2}

Następny werset interesującego nas fragmentu rozpoczyna nowy etap narracji, przedstawiając kolejną reakcję aniołów wobec sytuacji ludzkości - ich wzajemną rozmowę $e^{30}$.

Tabela 2. Greckie thumaczenia 1Hen 9,2

\begin{tabular}{|c|c|c|}
\hline Panopolitanus $\left(\mathrm{G}^{\mathrm{C}-1}\right)$ & Syncellus $\left(\mathrm{G}^{\mathrm{S}-1}\right)$ & Syncellus $\left(\mathrm{G}^{\mathrm{S}-2}\right)$ \\
\hline 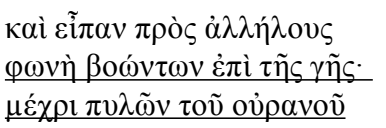 & 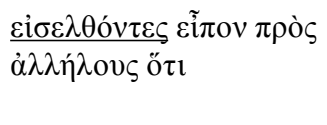 & 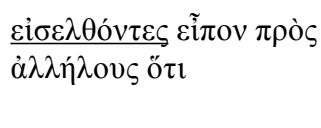 \\
\hline
\end{tabular}

Powyższe zestawienie ukazuje, iż tekst 1Hen 9,2 zawiera wprowadzenie do mowy niezależnej. Rozpoczynające wariant $\mathrm{G}^{\mathrm{C}-1}$ wyrażenie $\alpha a \grave{~} \varepsilon \tilde{i} \pi \alpha \nu$ (,,i powiedzieli”) swobodnie otwiera nowy rodzaj dyskursu. Inaczej dzieje się $\mathrm{w} \mathrm{G}^{\mathrm{S}-1} \mathrm{i}^{\mathrm{S}-2}$,

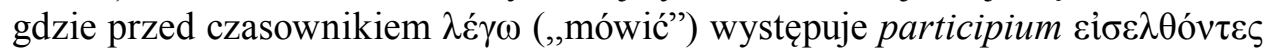
(,wszedłszy”) $)^{31}$, które zdaje się zachowywać łączność z wersetem poprzednim

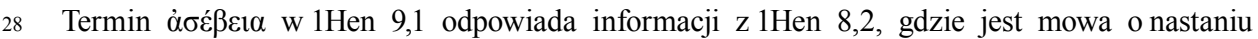

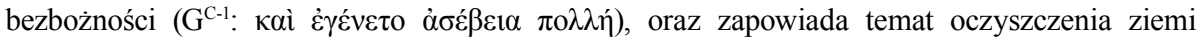

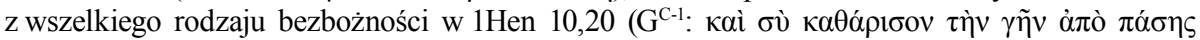

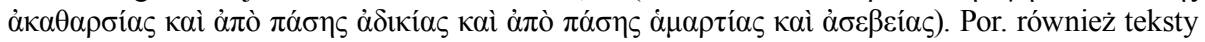
greckie (dotyczące także òvouía): 1Hen 1,9; 8,2; 10,20; 13,2; 97,6; 98,1.9; 99,15. Zob. Denis, Concordance grecque, 159, 188.

29 Dodatek obecny tylko $\mathrm{w} \mathrm{G}^{\mathrm{S}-1} \mathrm{i} \mathrm{G}^{\mathrm{S}-2}$, dotyczący zaistniałej na ziemi bezbożności i bezprawia, poświadczony jest przez tekst etiopski. Zachowany fragment aramejski 4Q201 fr.1 iv 7-8

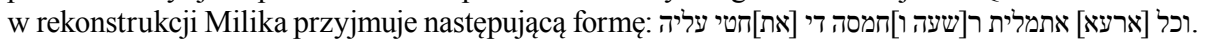

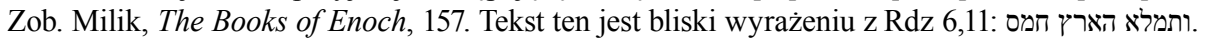
$\mathrm{Z}$ interpretacją tej rekonstrukcji polemizuje Nickelsburg, który formułę Milika „tak że grzech został na nią przyniesiony” odczytuje jako wyrażenie „grzechy, które spełniły się na niej”. Zob. Nickelsburg, 1 Enoch 1. A Commentary, 202-203.

30 Zob. Black, Apocalypsis Henochi Graece, 23; Mosshammer, Georgii Sincelli, 13, 24.

31 Czasownik ten, w 1 Hen $9,2\left(\mathrm{G}^{\mathrm{S}-1}, \mathrm{G}^{\mathrm{S}-2}\right)$ przypisany aniołom, może wskazywać na ich kultyczną, kapłańską aktywność - wejście do Miejsca Świętego (por. Ps 5,8; Mk 2,26; Łk 1,9; Hbr 9,12.24; Ap 15,8). Zob. Danker, A Greek-English Lexicon, 293-294; H. Balz - G. Schneider, Exegetical Dictionary of the New Testament (Grand Rapids, MI: Eerdmans 1990) I, 400. W podobnym 
bardziej niż wersja $\mathrm{G}^{\mathrm{C}-1}$. Jest to moment, kiedy aniołowie po zobaczeniu sytuacji na ziemi, przemieszczają się do wnętrza sanktuarium na wspólną naradę.

Można również zauważyć formułę zwrotną, występującą we wszystkich

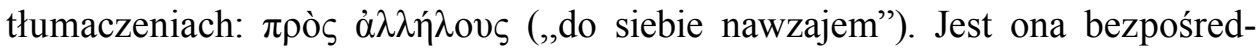
nim uzupełnieniem czasownika $\lambda \varepsilon^{\prime} \gamma \omega$. Po niej $\mathrm{w} \mathrm{G}^{\mathrm{s}-1} \mathrm{i} \mathrm{G}^{\mathrm{S}-2}$ występuje partykuła ö $\tau$ recitativum, wprowadzająca mowę niezależną i kończąca werset 1Hen 9,2. Odmienną sytuację dostrzegamy w kodeksie Panopolitanus, gdzie po formule zwrotnej pojawia się informacja dotycząca głosu krzyczących na ziemi aż do

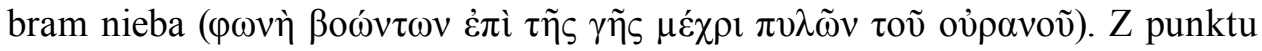
widzenia narracji jest ona powiązana z początkiem 1 Hen $9,3^{32}$.

\section{c) 1 Hen 9,3}

Do mowy niezależnej aniołów narrator wprowadza jej drugi stopień: do wypowiedzi istot niebiańskich włącza treść modlitwy błagalnej, którą umierająca ludzkość kieruje do aniołów jako pośredników przed Bogiem ${ }^{33}$.

Tabela 3. Greckie tłumaczenia 1Hen 9,3

\begin{tabular}{|c|c|c|}
\hline Panopolitanus $\left(\mathrm{G}^{\mathrm{C}-1}\right)$ & Syncellus $\left(\mathrm{G}^{\mathrm{S}-1}\right)$ & Syncellus $\left(\mathrm{G}^{\mathrm{S}-2}\right)$ \\
\hline 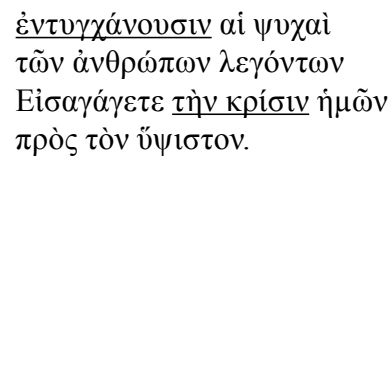 & 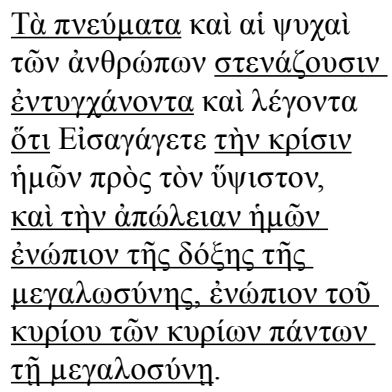 & 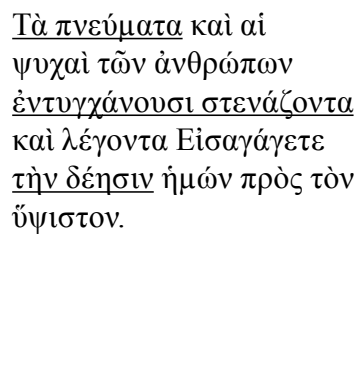 \\
\hline
\end{tabular}

Przygotowanie do mowy niezależnej błagających dusz (opis oskarżycieli) różni się $\mathrm{w}$ poświadczonych tłumaczeniach. $\mathrm{W} \mathrm{G}^{\mathrm{S}-1} \mathrm{i}^{\mathrm{S}-2}$ szczególnie podkreśla

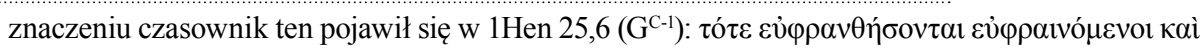

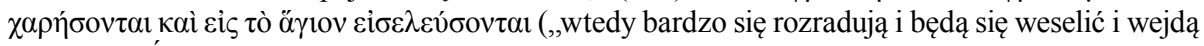
do Miejsca Świętego").

32 Takie odczytanie zakończenia tekstu greckiego 1Hen 9,2 proponuje Charles (zob. Charles, The

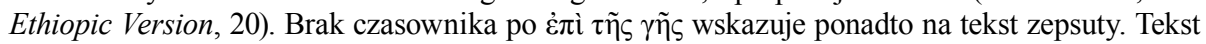
aramejski 1Hen 9,2 jest trudny do odtworzenia. Początek rekonstrukcji zaproponowanej przez Milika opiera się na wariantach Syncellusa dodając informację o ,słuchaniu” aniołów i przyjmuje

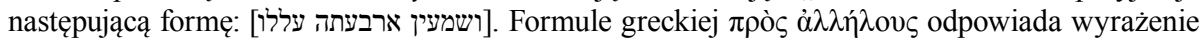
aramejskie, częściowo zrekonstruowane: [קדמ[יהן. Zob. Milik, The Books of Enoch, 160.

33 Zob. Black, Apocalypsis Henochi Graece, 23; Mosshammer, Georgii Sincelli, 13, 24. 
się rolę głównych bohaterów wersetu. Ludzkość jest tutaj zdefiniowana nie tylko

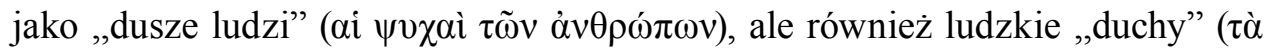
$\pi v \varepsilon v ́ \mu \alpha \tau \alpha)^{34}$. Natomiast $\mathrm{G}^{\mathrm{C}-1}$ używa jedynie wyrażenia $\alpha i$ $\psi v \chi \alpha i ̀ ~ \tau \tilde{\omega} v \dot{\alpha} v \theta \rho \omega ́ \pi \omega v$. Ponadto $\mathrm{w}$ kodeksie tym syntagma z poprzedniego wersetu $\mu \varepsilon^{\prime} \chi \rho \imath \pi \nu \lambda \tilde{\omega} \nu \tau o \tilde{v}$

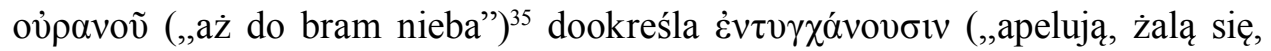
zwracają się z prośbą, wołają") ${ }^{36}$ w 1 Hen 9,3, co wówczas daje możliwość następującego tłumaczenia: ,aż do bram nieba zanoszą skargę dusze ludzi mówią-

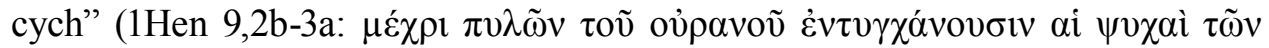
$\dot{\alpha} v \theta \rho \omega ́ \pi \omega v \lambda \varepsilon \gamma \delta \dot{v} \tau \omega v)^{37}$.

Kodeks Panopolitanus ogranicza się do informacji o skarżeniu się dusz

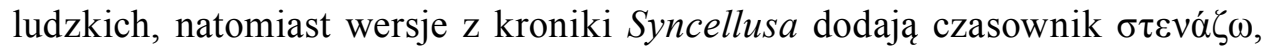
który oznacza wzdychanie i wyraża stan ducha zanoszących skargę ${ }^{38}$. Termin ten należy odczytywać w kontekście wołania dusz ludzkich aż do bram niebios ${ }_{\mathrm{w}} \mathrm{G}^{\mathrm{C}-1}$. Wydaje się, że jako nieobecny w owym manuskrypcie, zastąpiony jest

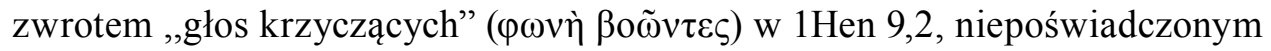
w $\mathrm{G}^{\mathrm{S}-1} \mathrm{i} \mathrm{G}^{\mathrm{S}-2}$.

34 Rekonstrukcja aramejska [נפשת בני אנשא] odpowiada bardziej $\mathrm{G}^{\mathrm{C}-1}$ oraz wersji etiopskiej. Zob. Milik, The Books of Enoch, 158, 171. Grecka informacja o duszach ludzi zapowiada werset 1 Hen

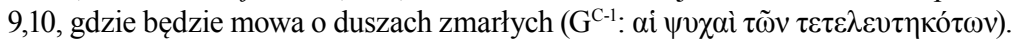

35 Formuła ta odpowiada aramejskiej wersji [.... [עד] תרעי שמי. Zob. Milik, The Books of Enoch, 157158. Pojawi się również uzupełniona zaimkiem w 1 Hen 9,10 , gdzie także będzie dotyczyć wołania

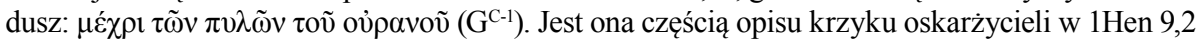
powiązaną tematycznie z wyrażeniami czasowymi dotyczącymi losu winowajców w 1 Hen 10,12

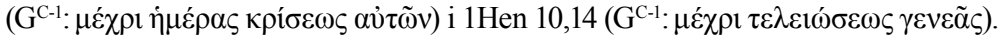

36 Ten rzadko występujący w Biblii czasownik wskazuje na apelowanie, zwracanie się z prośbą, odwoływanie się do kogoś (por. Dz 25,24), również jako skierowanie do Boga wyraża modlitwę (por. Mdr 8,21; 16,28; Rz 8,27.34; Hbr 7,25). Istotnym jego znaczeniem jest wyrażenie czynności skarżenia się, jak w 1Mch 8,32; 10,61.63-64; 11,25. Zob. Danker, A Greek-English Lexicon, 341.

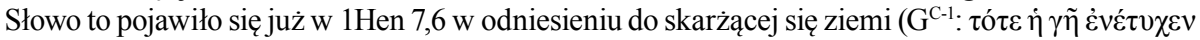

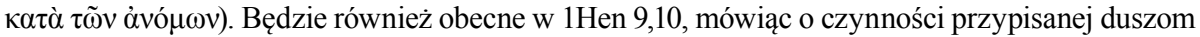

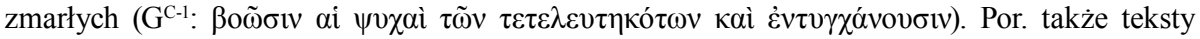
greckie 1Hen 22,5-7.12. Zob. Denis, Concordance grecque, 333-334. Aramejskim odpowiednikiem

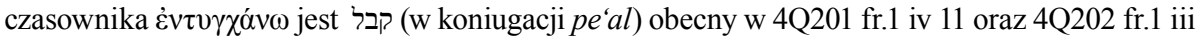
11. Zob. Cook, Dictionary, 203; Abegg, The Dead Sea Scrolls, 913.

37 Participium w 4Q202 fr.1 iii 11 oraz w całości w 4Q201 fr.1 iv 11. Zob. Milik, The Books of Enoch, 158, 171.

38 Czasownik ten oznacza wzdychanie powodowane tęsknotą za niebem (por. 2Kor 5,2.4; Rz 8,23), wzdychanie ze smutku (por. Mdr 5,3; Hbr 13,17), formę narzekania (por. 1Mch 1,26; Jk 5,9). Kiedy chodzi o teksty biblijne, to najczęściej pojawia się u Izajasza i Ezechiela (Iz 19,8; 21,2; 24,7; 30,15;46,8; 59,10; Ez 21,11-12; 26,15-16) i w Księdze Hioba (Hb 9,27; 18,20; 24,12; 30,25; 31,38), gdzie wiąże się z bólem związanym z odwróceniem się od Boga lub niezawinionym cierpieniem. Zob. Danker, A Greek-English Lexicon, 942. W Księdze Henocha termin ten pojawi się jeszcze w 1Hen 12,6 $\left(\mathrm{G}^{\mathrm{C}-1}\right)$ wyrażając lament upadłych Czuwających. 
Po wprowadzeniu do mowy niezależnej pojawia się czasownik w trybie roz-

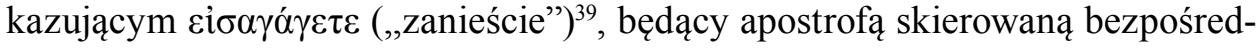
nio do aniołów. Następnie zostaje sprecyzowany rodzaj wypowiedzi dusz ludzkich. W tym kontekście podobieństwo występuje między tekstami $\mathrm{G}^{\mathrm{C}-1}$ i G $^{\mathrm{S}-1}$,

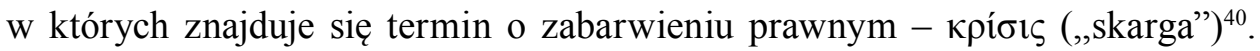
Natomiast $\mathrm{G}^{\mathrm{S}-2}$ mówi o błaganiu, petycji $(\delta \varepsilon ́ \eta \sigma ı)^{41}$, podkreślając $\mathrm{w}$ ten sposób wymiar błagalny i emocjonalny słów, które - według wszystkich trzech tłuma-

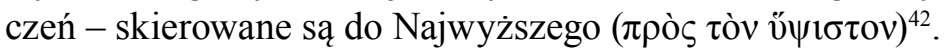

Dwa tematyczne elementy, tj. zaniesienie skargi/petycji oraz skierowanie jej do Najwyższego, zostają rozbudowane $\mathrm{w}$ wariancie $\mathrm{G}^{\mathrm{S}-1} \mathrm{o}$ informację o za-

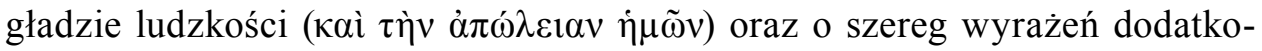
wo kwalifikujących Boga: ,przed Chwałę Majestatu, przed Pana wszystkich

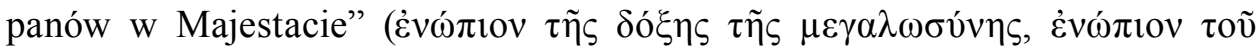

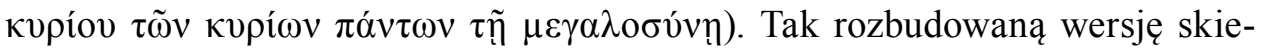
rowanej do aniołów wypowiedzi, jak również jej formę krótszą $\left(\mathrm{G}^{\mathrm{C}-1} \mathrm{i}^{\mathrm{S}-2}\right)$ można uznać za zakończenie jednostki 1Hen 9,1-3, w którym po raz pierwszy

39 Dosł. „wprowadźcie, przynieście”. Zob. Danker, A Greek-English Lexicon, 293; Balz - Schneider, Exegetical Dictionary, I, 400. W Corpus Henochicum słowo pojawi się jeszcze w kontekście zanoszonej modlitwy w 1Hen 99,3 jako przyniesienie grzechów nieprawych przed Najwyższego

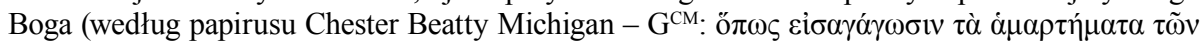

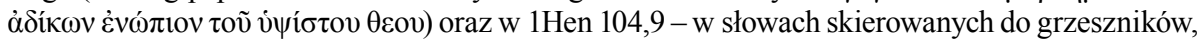

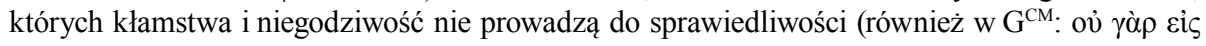

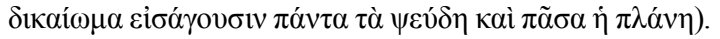

40 Termin ten pojawia się w Księdze Henocha wiele razy. Zob. Denis, Concordance grecque, 487488. Natomiast w micie 1 Hen $6-11$ jest obecny jeszcze w trzech miejscach. Po 1 Hen $9,4\left(G^{\mathrm{S}-1}\right)$

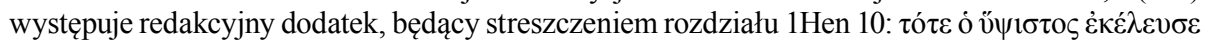

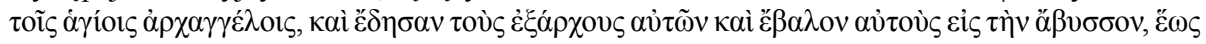

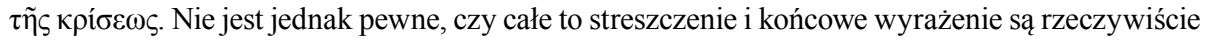
częścią teksu 1 Henocha. Drugie miejsce, gdzie pojawia się słowo kpíøıs, to 1Hen 10,6 - jest tam

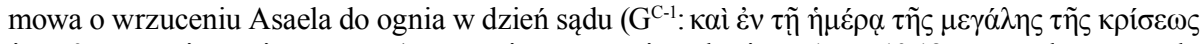

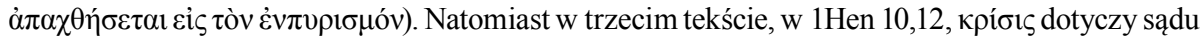

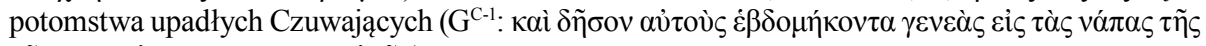

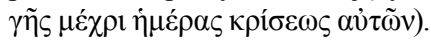

41 Należy zaznaczyć, iż poza rozumieniem tego terminu jako modlitwy, prośby skierowanej do Boga, słowo to może mieć również charakter jurydyczny i oznaczać „petycję” skierowaną także do człowieka (por. 1Mch 11,49). Zob. Danker, A Greek-English Lexicon, 213; B.M. Newman, Greek-English Dictionary of the New Testament (Stuttgart: Deutsche Bibelgesellschaft, 1993) 1379.

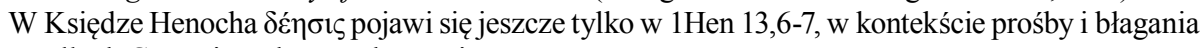
upadłych Czuwających o przebaczenie.

42 Mowa tu o Najwyższym w sensie statusu, Najwyższym Bogu, odróżniającym się od mniejszych bóstw i innych obiektów kultu. W takim znaczeniu słowo to występuje w tekstach biblijnych i literaturze międzytestamentalnej. Najczęściej pojawia się w Psalmach, Księdze Syracha i Księdze Daniela. W Nowym Testamencie jest terminem charakterystycznym dla Łukasza. W greckich apokryfach wiele razy pojawia się w Wyroczni Sybilijskiej, natomiast w Księdze Henocha jeszcze w 1Hen 9,2; 10,1; 98,7; 99,3.10; 100,4; 101,1.6. Zob. Danker, A Greek-English Lexicon, 1045; Denis, Concordance grecque, 766 . 
pojawia się informacja o Bogu - tym, który będzie miał najważniejszy wpływ na bieg akcji w dalszych częściach mitu.

\subsection{Wewnętrzny podział 1 Hen $9,1-3$}

Powyższe obserwacje wykazują, iż 1Hen 9,1-3, mimo że stanowi pod względem literackim krótki epizod w micie 1Hen 6-11, zawiera szereg ważnych szczegółów oraz wiadomości dotyczących bohaterów i świata opowiadania. Występują w nim trzy główne bloki tematyczne: prezentacja archaniołów i opis sytuacji na ziemi (1Hen 9,1), wzajemna rozmowa aniołów (1Hen 9,2) oraz przytoczona przez nich skarga dusz ludzi (1Hen 9,3). Dwa ostatnie tematy stanowią jeden blok dotyczący mowy aniołów (1Hen 9,2-3).

\section{a) Prezentacja archaniołów (1Hen 9,1a-b)}

Pierwsza z dwóch głównych części wersetu 1Hen 9,1 opisuje reakcję aniołów przebywających w niebie. Poprzednie analizy pozwalają zauważyć w niej dwa elementy szczegółowe (1Hen 9,1a-b).

- 1Hen 9,1a - sytuacja w niebie, cz. 1: opis aniołów i ich czynności

Panopolitanus $\left(\mathrm{G}^{\mathrm{C}-1}\right)$ podaje imiona aniołów i informację o ich patrzeniu/wychylaniu się z nieba ( $\pi \alpha \rho \alpha \kappa v ́ \pi \tau \omega)$. Syncellus $\left(\mathrm{G}^{\mathrm{S}-1}, \mathrm{G}^{\mathrm{S}-2}\right)$ najpierw odnotowuje wysłu-

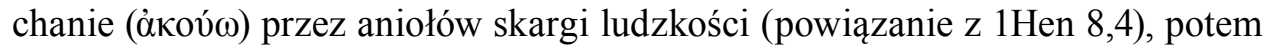
podaje ich liczbę, kwalifikuje istoty nadprzyrodzone jako wielkich archaniołów oraz przywołuje ich imiona.

- 1Hen 9,1b - sytuacja $w$ niebie, cz. 2: miejsce przebywania aniołów i ich patrzenie

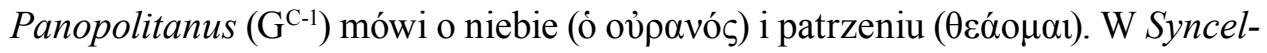

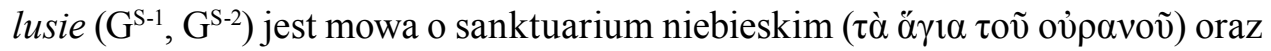
patrzeniu na dół, wyglądaniu ( $\pi \alpha \rho \alpha \kappa v ́ \pi \tau \omega)$.

\section{b) Opis sytuacji na ziemi (1Hen 9,1c-d)}

Druga część wersetu 1Hen 9,1 dotyczy tragicznej sytuacji ziemi. W przypadku $\mathrm{G}^{\mathrm{C}-1}$ opis ogranicza się do jednego elementu, natomiast według $\mathrm{G}^{\mathrm{S}-1}, \mathrm{G}^{\mathrm{S}-2}$ występuje wraz $\mathrm{z}$ dodatkiem (1Hen 9,1c-d). 
-1Hen 9,1c - sytuacja na ziemi: informacja o krwi rozlanej na ziemi

Zarówno w Panopolitanus $\left(\mathrm{G}^{\mathrm{C}-1}\right)$, jak i w świadectwie Syncellusa $\left(\mathrm{G}^{\mathrm{S}-1}, \mathrm{G}^{\mathrm{S}-2}\right)$ jest obecna ta sama informacja. $\mathrm{W} \mathrm{G}^{\mathrm{C}-1}$ bezpośrednio łączy się $\mathrm{z}$ treścią $1 \mathrm{Hen}$ 9,1b (rozlaną krew na ziemi „oni zobaczyli z nieba”). W G ${ }^{\mathrm{S}-1}, \mathrm{G}^{\mathrm{S}-2}$ zostaje dodatkowo podkreślona czynność patrzenia $(\theta \varepsilon \alpha ́ o \mu \alpha \imath)$ poprzedzona spójnikiem, co pozwala przypisać ją do kolejnej, osobnej części wersetu: spojrzeli z nieba na ziemię (zob. 1Hen 9,1b), po czym zobaczyli dużą ilość krwi (1Hen 9,1c: кaì $\theta \varepsilon \alpha \sigma \alpha ́ \mu \varepsilon v o r ~ \alpha \tilde{i} \mu \alpha \pi \mathrm{o} \lambda \dot{v})$.

- 1Hen 9,1d - sytuacja na ziemi, cz. 2: informacja o bezbożności i bezprawiu $\left(G^{S-1}, G^{S-2}\right)$

Jest to dodatek znajdujący się tylko w wariantach z kroniki Syncellusa $\left(\mathrm{G}^{\mathrm{S}-1}\right.$, $\mathrm{G}^{\mathrm{S}-2}$ ), w których występuje różnica dotycząca kolejności występowania terminów: $\mathrm{w}^{\mathrm{S}-1}$ jest mowa o bezbożności i bezprawiu, natomiast $\mathrm{w}^{\mathrm{S}-2} \mathrm{o}$ bezprawiu i bezbożności.

\section{c) Mowa aniołów (1Hen 9,2-3)}

Struktura wersetów 1Hen 9,2-3 składa się z pięciu części: wprowadzenia mowy aniołów wraz z ich wejściem do sanktuarium (1Hen 9,2a), wprowadzenia do wypowiedzi dusz ludzkich (jego początek $\mathrm{w}^{\mathrm{C}-1}$ znajduje się w 1 Hen $9,2 \mathrm{~b}$, natomiast według $\mathrm{G}^{\mathrm{S}-1}, \mathrm{G}^{\mathrm{S}-2}$ dopiero w $1 \mathrm{Hen} 9,3 \mathrm{a}$ ) oraz kolejnych elementów mowy dusz ludzi (1Hen 9,3b-d).

- 1Hen 9,2a - formuła wprowadzająca mowę niezależna oraz wejście aniołów do sanktuarium

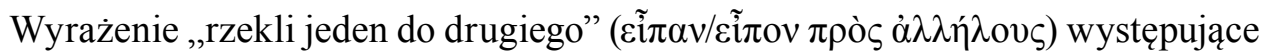
we wszystkich trzech świadkach tekstu jest przygotowaniem do mowy niezależnej. W tekstach $\mathrm{G}^{\mathrm{S}-1}, \mathrm{G}^{\mathrm{S}-2}$ zostało poszerzone o partykułę ö $\tau \imath$ oraz poprzedzo-

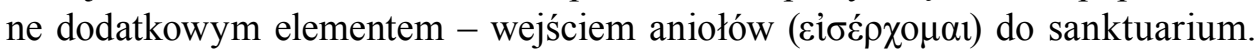
Wejście to wydaje się być bezpośrednią zapowiedzią modlitwy błagalnej wobec Boga (zob. 1Hen 9,4-11).

- 1 Hen 9,2b $\left(G^{C-1}\right)$-3a - wprowadzenie do mowy dusz ludzkich

Kodeks Panopolitanus $\left(\mathrm{G}^{\mathrm{C}-1}\right)$ podaje informację o krzyku wołających na ziemi

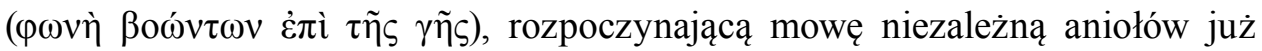

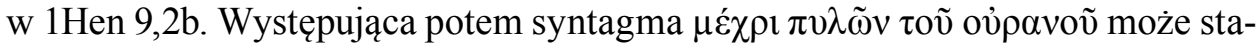


nowić wyrażenie okolicznikowe będące częścią zdania w 1Hen 9,3a mówiącego o zanoszeniu skargi przez ludzkość. Z kolei Syncellus $\left(\mathrm{G}^{\mathrm{S}-1}, \mathrm{G}^{\mathrm{S}-2}\right)$ wprowadza bezpośrednią wypowiedź aniołów i przygotowuje mowę niezależną dusz ludzi dopiero w 1Hen 9,3a.

W 1Hen 9,3a, zarówno w Panopolitanus $\left(\mathrm{G}^{\mathrm{C}-1}\right)$, jak i Syncellusie $\left(\mathrm{G}^{\mathrm{S}-1}, \mathrm{G}^{\mathrm{S}-2}\right)$,

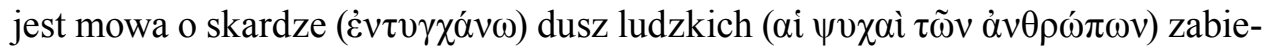
rających głos (participium czasownika $\lambda \dot{\varepsilon} \gamma \omega$, w przypadku $\mathrm{G}^{\mathrm{S}-1}$ wraz z partykułą ö $\tau)$. $\mathrm{W} \mathrm{G}^{\mathrm{S}-1}, \mathrm{G}^{\mathrm{S}-2}$ są obecne dodatkowe elementy w 1 Hen $9,3 \mathrm{a}$, do których należą: czynność wzdychania ( $\sigma \tau \varepsilon v \alpha ́ \zeta \omega)$ oraz wiadomość o ludzkich duchach ( $\tau \grave{\alpha} \pi v \varepsilon v ́-$

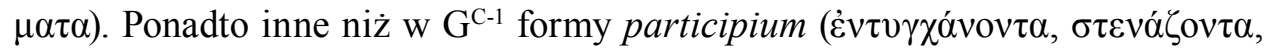

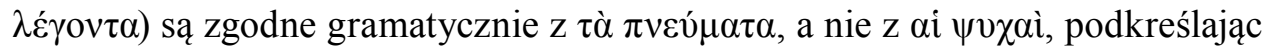
$\mathrm{w}$ ten sposób rolę pierwszego terminu w tekstach z kroniki Syncellusa.

\section{-1Hen 9,3b - treść skargi: zaniesienie oskarżenia/skargi lub błagania}

We wszystkich trzech świadectwach treść skargi rozpoczyna się od trybu rozkazującego. W kodeksie Panopolitanus $\left(\mathrm{G}^{\mathrm{C}-1}\right)$ oraz w pierwszym fragmencie z kro-

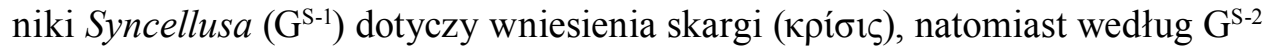

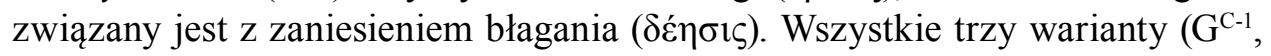
$\mathrm{G}^{\mathrm{S}-1}, \mathrm{G}^{\mathrm{S}-2}$ ) mówią o adresacie skargi/błagania - Najwyższym (v̛ $\left.\psi 1 \sigma \tau \varsigma \varsigma\right)$.

- 1Hen 9,3c - treść skargi, cz. 2: informacja o zagładzie $\left(G^{S-1}\right)$

Informacja o zagładzie ( $\alpha \dot{\pi} \omega \dot{\lambda} \varepsilon 1 \alpha)$ ludzkości pojawia się tylko w pierwszym fragmencie Syncellusa $\left(\mathrm{G}^{\mathrm{S}-1}\right)$. Dodanie tego elementu nastąpiło na podstawie tekstów 1Hen 7,2-5 i 1Hen 8,4 według kodeksu Panopolitanus $\left(\mathrm{G}^{\mathrm{C}-1}\right)$ i drugiego fragmentu Syncellusa $\left(\mathrm{G}^{\mathrm{S}-2}\right)$. Ponadto występuje tutaj metaforyczne określenie Boga: „Chwała Majestatu” (por. 1Hen 8,4 według $\mathrm{G}^{\mathrm{S}-2}$ ).

-1Hen 9,3d-treść skargi, cz. 3: dodatkowy tytuł Boga $\left(G^{S-1}\right)$

Jest to dodatek obecny tylko w pierwszym fragmencie Syncellusa $\left(\mathrm{G}^{\mathrm{S}-1}\right)$ : „Pan

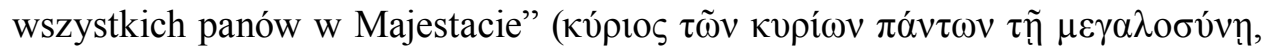
por. 1 Hen $\left.8,4 \mathrm{w} \mathrm{G}^{\mathrm{S}-2}\right)$.

\subsection{Struktura 1 Hen $9,1-3$}

Podsumowując pierwszą część niniejszego artykułu, można wyróżnić strukturę 1Hen 9,1-3, opartą na rozwoju narracji przebiegającym w trzech głównych etapach. Jak wykazały powyższe analizy, każdy z wersetów posiada swój własny wewnętrzny podział i dynamikę narracji, które pozwalają zaznaczyć jeszcze 
jeden zabieg literacki. Jest nim rozwinięcie w 1Hen 9,2-3 tematów zapowiedzianych w 1 Hen 9,1. Pierwszym sygnałem pozwalającym na takie rozumienie tekstu jest wyjaśnienie w 1Hen 9,2, co dokładnie dzieje się w przestrzeni niebiańskiej. Aniołowie, którzy w 1Hen 9,1 milczeli, przyglądali się oraz słuchali, stają się w 1Hen 9,2 aktywni, jakby bliżsi i bardziej znani z powodu udzielenia im głosu przez narratora. $W$ ten sposób zostaje zinterpretowana ich wcześniejsza reakcja, zawarta przede wszystkim w punktach 1 Hen $9,1 \mathrm{a}-\mathrm{b}^{43}$. Z kolei skierowanie uwagi czytelnika w 1Hen 9,3 na przestrzeń ziemską wprowadza tematykę obecną w 1Hen 9,1. Opis dramatu cierpiącej ludzkości w 1Hen 9,1c-d miał bowiem charakter ogólny i narracyjnie zdystansowany. Natomiast w 1Hen 9,3, dzięki dopuszczeniu do głosu samych mieszkańców ziemi, temat ten staje się znów aktualny, opowiedziany tym razem z perspektywy tych, którzy uczestniczą w owej tragedii wraz z ich obawami i oczekiwaniami.

Tabela 4. Struktura 1Hen 9,1-3

1. Sytuacja w niebie (1Hen 9,1a-b)

1.1. Opis aniołów $(9,1 \mathrm{a})$

1.2. Miejsce przebywania aniołów $(9,1 \mathrm{~b})$

2. Sytuacja na ziemi (1Hen 9,1c-d)

2.1. Krew rozlana na ziemi $(9,1 \mathrm{c})$

2.2. Bezbożność i bezprawie zaistniałe na ziemi $\left(\mathrm{G}^{\mathrm{S}-1}, \mathrm{G}^{\mathrm{S}-2}\right)(9,1 \mathrm{~d})$

3. Mowa aniołów (1Hen 9,2-3)

3.1. Formuła wprowadzająca mowę niezależną i wejście do sanktuarium $(9,2 a)$

3.2. Wprowadzenie do mowy dusz ludzkich $\left(9,2 \mathrm{~b}\left[\mathrm{G}^{\mathrm{C}-1}\right]-3 \mathrm{a}\right)$

3.3. Mowa dusz ludzkich $(9,3 \mathrm{~b}-\mathrm{d})$

3.3.1. Zaniesienie skargi/błagania $(9,3 \mathrm{~b})$

3.3.2. Informacja o zagładzie $\left(\mathrm{G}^{\mathrm{S}-1}\right)(9,3 \mathrm{c})$

3.3.3. Dodatkowy tytuł Boga $\left(\mathrm{G}^{\mathrm{S}-1}\right)(9,3 \mathrm{~d})$

43 W 1Hen 9,1-3 zachodzi zjawisko zmiany perspektywy: przejście z perspektywy zerowej (wydarzenia ukazane z punktu widzenia wszechwiedzącego narratora w 1 Hen 9,1) do perspektywy wewnętrznej (te same zdarzenia opowiedziane przez jednego $z$ bohaterów - aniołów w 1Hen 9,2 oraz dusze ludzkie w 1Hen 9,3). W przypadku 1Hen 9,1 trudno mówić o perspektywie zewnętrznej, gdyż opis dotyczy zdarzeń mających miejsce w przestrzeni nadprzyrodzonej - niedostępnej dla neutralnego, zwykłego widza. Zob. B. Rzepka, „Pytanie o właściwą metodologię analizy narracyjnej”, Biblica et Patristica Thoruniensia 11/2 (2018) 156-157. 


\section{Tekst 1Hen 9,1-3 w kontekście mitu 1Hen 6-11}

Należy zauważyć, iż zaprezentowana wyżej analiza literacka wersetów 1Hen 9,1-3 oraz ich wewnętrzny podział tematyczny nawiązują również do innych elementów 1Hen 6-11. Poniżej zostanie ukazane, w jaki sposób tekst 1Hen 9,1-3 spełnia istotną rolę w swym najbliższym kontekście (§3.1), ukazuje sens logiczny zdarzeń w strukturze mitu (§3.2), pomaga lepiej zrozumieć pozostałe jego części (§3.3) oraz stanowi w nim moment przełomowy (§3.4).

\subsection{Hen 9,1-3 jako scena początkowa}

Wiadomości zawarte w tekście 1Hen 9,1-3 pozwalają uznać go za istotne wprowadzenie do opowiadania o wstawiennictwie aniołów na rzecz ludzkości 1Hen 9 (w analizie narracyjnej zwane ekspozycją, sceną początkową) ${ }^{44}$. Wersety 1 Hen 9,1-3 zawierają sygnały, które okazują się pomocne, a nawet niezbędne, dla właściwego odczytania dalszego biegu zdarzeń w 1Hen 9,4-11.

Wcześniejsze analizy ukazały, iż wiersze 1Hen 9,1-3 zawierają szczegółowy opis aniołów oraz dusz (i duchów) ludzi. Spełniają oni ważne role w dalszej narracji - 1Hen 9,4-11. Czterej wielcy archaniołowie znani z 1Hen 9,1 są od 1Hen 9,4 głównymi bohaterami akcji jako jej narratorzy ${ }^{45}$. Natomiast dusze ludzi są postaciami drugoplanowymi, jednakże ich ponowne pojawienie się w 1Hen 9,10 służy połączeniu części 1Hen 9,4-11 z 1Hen 9,1-3 oraz przypomnieniu tematu cierpiącej ludzkości z 1Hen 7,6 i 1Hen 8,4.

Zauważone w poprzednim paragrafie wiadomości dotyczące sytuacji w niebie stanowią przygotowanie do treści modlitewnej w 1Hen 9,4-5. Pierwszym ważnym sygnałem jest podkreślenie, iż aniołowie z 1Hen 9,1 pozostają w ścisłym związku z Bogiem ${ }^{46}$ oraz przebywają w przestrzeni niebiańskiej (zob. §2.1;

44 Ekspozycja zawiera podstawowe informacje, pomocne we właściwym zrozumieniu reakcji bohaterów, pojawienia się ich w opowiadaniu oraz innych czynników mających wpływ na dalszy rozwój akcji. Jest to moment graniczny opowiadania, scena początkowa. Zob. A. Węgrzyn, Postawy wobec Jezusa ofiarujacego miłość. Analiza narracyjna (Łk 7,36-50) (Studia Biblica Lublinensia 16; Lublin: Wydawnictwo KUL 2016) 30.

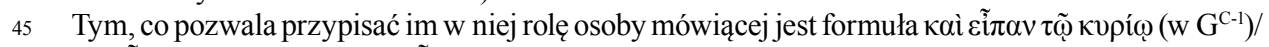

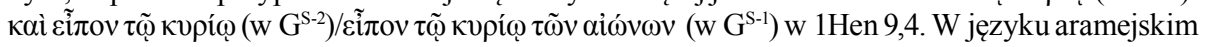
formuła nie zachowała się. Natomiast Milik, w świetle zachowanych fragmentów wersetu 1Hen אמרו קודם מרא עלמא : 9,4 oraz innych tekstów 1Hen, zaproponował następującą jej rekonstrukcję (,powiedzieli wobec Pana świata”). Zob. Milik, The Books of Enoch, 171.

46 Mówi o tym znaczenie ich imion, zawierających cząstkę -í $\lambda$, która wskazuje na samego Boga. Zob. F. Brown - S. Driver - C. Briggs, The Brown-Driver-Briggs Hebrew and English Lexicon: With an Appendix Containing the Biblical Aramaic (Oxford: Clarendon Press 1907) 41; L. Koehler - W. Baumgartner, Wielki stownik hebrajsko-polski i aramejsko-polski Starego Testamentu 
2.2a). Te dwa elementy budują atmosferę niebiańską/liturgiczną i stanowią podstawę dla wprowadzenia w narrację doksologii (1Hen 9,4-5) ${ }^{47}$.

Ponadto miejsce wydarzeń oraz czas akcji ${ }^{48}$ znane z 1Hen 9,1-3 nie tylko nie zmieniają się przez całą narrację 1Hen 9,1-11, ale zostają później bardziej wyróżnione przez odpowiednie sygnały literackie: przestrzeń niebiańska dzięki informacji o przystąpieniu ( $\pi \rho 0 \sigma \varepsilon \lambda \theta$ óv $\tau \varepsilon \varsigma$ ) aniołów w 1Hen 9,4 przed tron Najwyższego Boga, natomiast czas wydarzeń poprzez pojawienie się terminu võv (,teraz”) w 1 Hen $9,10^{49}$.

Informacje związane ze stanem ludzkości w 1Hen 9,1-3 zapowiadają włączony w strukturę anielskiej modlitwy szczegółowy opis ziemskiego dramatu. Kilka wiadomości zawartych w 1Hen 9,4-11 potwierdza, iż treść wersetów 1Hen 9,1c-d (krew rozlana na ziemi, bezbożność i bezprawie), 1Hen 9,2b (krzyk wołających), 1Hen 9,3b-c (zanoszona skarga i wiadomość o zagładzie) ma istotny wpływ na właściwe odczytanie anielskiego raportu w 1Hen 9,6-10. Wiadomość o rozlanej krwi w 1Hen 9,1 zapowiada informacje na ten temat w 1Hen 9,9 (ő $\lambda \eta$

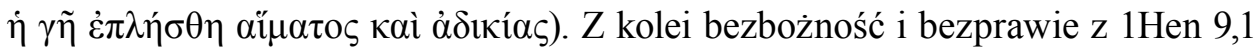
można łączyć z opisem czynów Asaela w 1Hen 9,6 i Szemichazy w 1Hen 9,7-8. Natomiast przytoczony przez aniołów motyw skargi dusz ludzi w 1Hen 9,3 jest paralelny do informacji na ten temat w 1Hen 9,10 (zob. §2.1). Podobnie dzieje się w sytuacji wiadomości o Najwyższym w 1 Hen 9,3, która bezpośrednio przygotowuje doksologię w 1Hen 9,4-5 oraz stanowi klamrę literacką ze zwróceniem się do Boga w 1 Hen $9,11^{50}$.

Wymienione wyżej powiązania przedstawiają zatem wersety 1Hen 9,1-3 jako sekcję (rozumianą jako ekspozycję) sygnalizującą tematy później rozwinięte według poniższego schematu:

(Warszawa: Vocatio 2013) I, 47-48. Ponadto jest uzupełniona o treść dotyczącą jakiejś szczególnej cechy Boga lub roli Bożego posłańca.

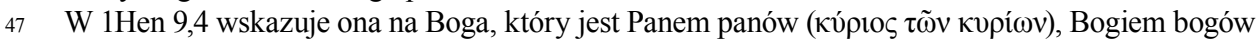

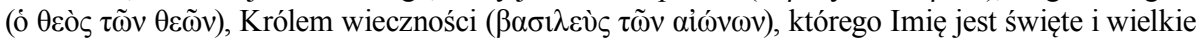

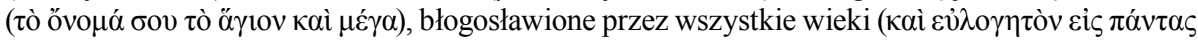

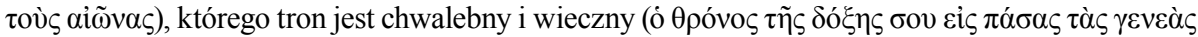

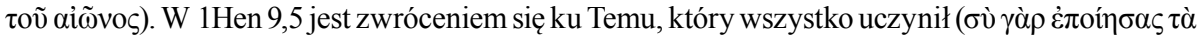

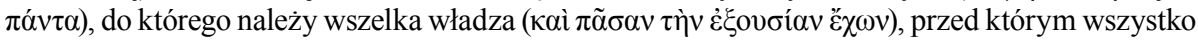

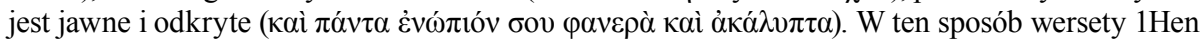
9,4-5 znacząco przypominają rozbudowany element modlitwy dusz zmarłych z $\mathrm{G}^{\mathrm{S}-1}$ (1Hen 9,3c-d). To tematyczne podobieństwo jeszcze bardziej umacnia związek wersetów 1Hen 9,1-3 i 1Hen 9,4-5, czyniąc je częścią opowiadania 1Hen 9,1-11, która dotyczy bezpośrednio przestrzeni świętej.

48 Słowo $\tau$ ó $\tau \varepsilon \mathrm{w} 1$ Hen $9,1\left(\mathrm{w} \mathrm{G}^{\mathrm{C}-1}\right)$ nosi w sobie bowiem także aspekt czasowy, spełniając funkcję przysłówka - należy więc je tłumaczyć jako „wówczas, wtedy” (por. 1Hen 6,5; 7,6; 10,1).

49 Jego aramejski odpowiednik przełomu w narracji, szczególnie w tekstach modlitewnych (por. Dn 2,23).

50 W wersecie 1Hen 9,11 aniołowie zwracają się do Boga jako tego, który zna wszystko, zanim się

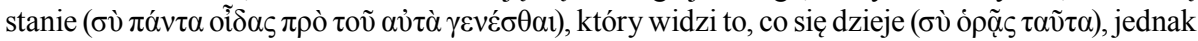

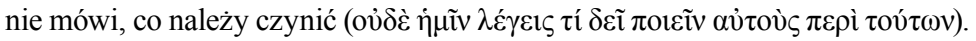


1. Scena początkowa (1Hen 9,1-3)

2. Doksologia (1Hen 9,4-5)

3. Czyny Asaela (1Hen 9,6)

4. Czyny Szemichazy (1Hen 9,7-8)

5. Spisek Czuwających i jego konsekwencje (1Hen 9,9)

6. Odwołanie do skargi dusz zmarłych ludzi $(1$ Hen 9,10)

7. Scena końcowa (1Hen 9,11)

\subsection{Hen 9,1-3 jako element konstytutywny}

Sekcja 1Hen 9,1-3 jest elementem konstytutywnym mitu (w teorii narracji zwanym również elementem pierwszorzędnym, punktem węzłowym) ${ }^{51}$, ponieważ ukazuje sens logiczny zdarzeń mających miejsce w rozdziale następnym - 1Hen 10. Omówione w powyższych paragrafach działanie aniołów w 1 Hen 9,1-2 oraz prośba o wstawiennictwo skierowana do nich w 1 Hen 9,3 są epizodami, bez których - z punktu widzenia narracji - późniejsze zdarzenia nie miałyby miejsca.

Aniołowie słysząc skargę/wołanie dusz ludzkich, przyglądają się sytuacji na ziemi, po czym rozmawiają o tym między sobą. Wysłuchują prośbę i podejmują modlitwę, w której zdają raport Bogu o zauważonej przez nich sytuacji na ziemi oraz usłyszanej lamentacji cierpiącej ludzkości. Kierując do Boga modlitwę w jej intencji, aniołowie oczekują odpowiedzi, która następuje w 1Hen 10,116a. Tak zarysowany kontekst relacji między 1 Hen 9,1-3 i 1Hen 10,1-16a dotyczy kilku informacji zawartych w 1Hen 9,1-3, które odnajdują swoje odzwierciedlenie w bloku 1Hen 10,1-16a. Najbardziej istotną jest odnotowana w świadectwach $\mathrm{G}^{\mathrm{S}-1}, \mathrm{G}^{\mathrm{S}-2}$ wiadomość o czterech aniołach w 1 Hen 9,1 , która dotyczy czterech aniołów posłanych przez Boga w 1Hen 10: Istraela (1Hen 10,1-3) $)^{52}$, Rafała (1Hen 10,4-8), Gabriela (1Hen 10,9-10) i Michała (1Hen 10,11-16a).

Pierwszy opis posłania znajdujący się w 1Hen 10,1-3 dotyczy dotarcia pierwszego z czterech aniołów do syna Lamecha $(1$ Hen 10,1$)$ z wiadomością o zbliżającym się zniszczeniu ziemi (1Hen 10,2) ${ }^{53}$. Anioł ma go pouczyć, jak uciec

51 Punkty węzłowe, elementy pierwszorzędne, rdzenie ukazują alternatywne rozwiązania dotyczące wyborów i działań mających wpływ na rozwój narracji. W jednym opowiadaniu poszczególne punkty węzłowe są wzajemnie od siebie zależne. Wytyczając kierunek narracji, tworzą jej podstawowy schemat. Zob. J. Czerski, Metodologia Nowego Testamentu (Opolska Biblioteka Teologiczna 26; Opole: RW UO 2012) 149.

52 Istnieją rozbieżności związane z imieniem anioła posłanego w 1 Hen 10,1. Według tekstów greckich jest nim Istrael $\left(\mathrm{w} \mathrm{G}^{\mathrm{C}-1}\right)$ lub Uriel $\left(\mathrm{G}^{\mathrm{S}}\right)$. W etiopskim tłumaczeniu występuje Arsjalaljur. Wszystkie te wersje w jakimś stopniu związane są z Sarielem obecnym w tekście aramejskim.

53 Grecki tekst 1Hen 10,1-3 zachowuje kodeks Panopolitanus i jeden fragment z kroniki Syncellusa $\left(\mathrm{G}^{\mathrm{S}}\right)$. Na temat tego opisu w kontekście literatury mezopotamskiej zob. H. Drawnel, „Ukaranie 
przed karą potopu (1Hen 10,3) ${ }^{54}$. Misja ta związana jest zatem z działalnością Boga, który dokonuje czynów destrukcyjnych wobec niesprawiedliwych, prawych chce zaś zachować i uczynić „rośliną sprawiedliwości” (zob. 1Hen 10,16b19). Biorąc pod uwagę związek tego opisu z obecnością Uriela w 1Hen 9,1, który miałby odpowiadać posłańcowi z 1Hen 10,1, sekcja 1Hen 10,1-3 jawi się jako zapowiedź przekleństwa, które dotknie ziemię skażoną nieprawością. Sytuacja ta oddaje sens imienia anioła: Oủpı̀̀ (אוריאל, ,ogień Boży” ${ }^{55}$ ) to anioł mówiący o Bogu jako pogromcy, zwiastujący drżenie i zagładę (zob. 1Hen 10,20.22a).

Kolejne posłanie obecne w 1Hen 10,4-8 stanowi dwuetapową misję Rafa$\mathfrak{l a}^{56}$. W pierwszej części dotyczy związania Asaela i wrzucenia go do ciemności (1Hen 10,4-6), natomiast w drugiej mówi o ożywieniu ziemi i zapowiedzi jej uzdrowienia (1Hen 10,7-8). Zadaniem anioła posłanego w 1 Hen 10,4 jest więc zwiastowanie kresu choroby spowodowanej działalnością dydaktyczną Asaela -

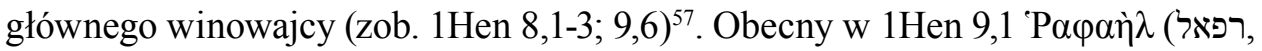
„Bóg uleczy”58) w 1Hen 10,4-8 wskazuje na Boga, który leczy i przywraca to, co umarłe do życia (zob. 1Hen 10,16b-19).

Trzecim archaniołem posłanym przez Pana w 1 Hen 10,9-10 jest Gabriel ${ }^{59}$.

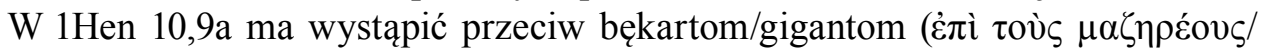

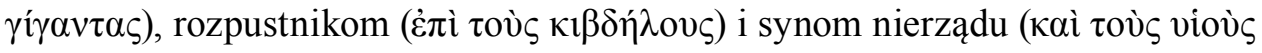

Asaela (1 Hen. 10,4-8) w kontekście mezopotamskiej literatury zwalczającej czarną magię", Biblical Annals 3 (2013) 285-307.

54 Molenberg zauważa związek między obecnym tutaj terminem $\delta \eta ́ \lambda \omega \sigma o v ~ d o t y c z a ̨ c y m ~ p o u c z e n i a /$ pokazania i tą samą czynnością podjętą wcześniej przez Szemichazę (por. 1Hen 7,1; 9,8) i Asaela (1Hen 9,6). Autor podkreśla, iż nauczanie aniołów w 1Hen 7-8 i 1Hen 10,1 skierowane jest do ludzi, przy czym w 1 Hen 10 jest usankcjonowane przez Boga, natomiast w sytuacji działalności upadłych Czuwających funkcjonuje poza prawem Bożym. W misji Rafała pouczenie/pokazanie

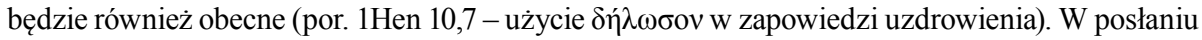
Michała czynność ta łączy się z motywem oczyszczenia (por. 1Hen 10,11 - zastosowanie $\delta \eta ́ \lambda \omega \sigma o v$ w opisie pouczenia Szemichazy). Zob. Molenberg, „A Study of the Roles”, 140.

55 W greckim tekście Księgi Henocha Uriel wystąpi jeszcze w 1Hen 19,1, wskazując miejsce przebywania aniołów po ich upadku aż do dnia sądu; w 1Hen 20,2 jest ukazany jako jeden ze świętych aniołów, anioł gromu i drżenia, a w 1 Hen 21,5 jako przewodnik Henocha. Por. również jego rolę w 2Ezd 4,1; 5,20; 10,28. Zob. Myers, The Eerdmans Bible Dictionary, 1031-1032; C.A. Newsom, "Uriel (Angel)", The Anchor Yale Bible Dictionary (ed. D.N. Freedman) (New York: Doubleday 1992) VI, 769.

56 Tekst grecki zachowany $\mathrm{w}^{\mathrm{C}-1}$ oraz $\mathrm{G}^{\mathrm{S}}$.

57 Na temat działalności dydaktycznej Asaela i jej mezopotamskiego zaplecza pojęciowego zob. H. Drawnel, „Zawodowa wiedza Asaela (1 Hen. 8,1) i jej relacja do starożytnej Mezopotamii”, Biblical Annals 3 (2013) 47-66.

58 W greckim tekście Księgi Henocha Rafał pojawi się jeszcze w 1Hen 20,3 (jeden ze świętych aniołów, anioł duchów ludzkich), w 1Hen 22,3 (przewodnik Henocha) oraz w 1Hen 32,6 (święty anioł, ukazujący drzewo poznania). Jest opiekunem Tobiasza i przeciwnikiem ducha Asmodeusza w Tb 3,16; 5,4; 7,9; 8,2; 9,1.5; 11,1.7; 12,15. Zob. Myers, The Eerdmans Bible Dictionary, 873; F.W Schmidt, "Raphael (Angel)", The Anchor Yale Bible Dictionary (ed. D.N. Freedman) (New York: Doubleday 1992) V, 621.

59 Opis zachował się w dwóch wersjach greckich: $\mathrm{G}^{\mathrm{C}-1} \mathrm{i} \mathrm{G}^{\mathrm{S}}$. 


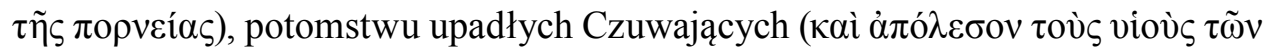
$\dot{\varepsilon} \gamma \rho \eta \gamma o ́ \rho \omega v)$ i spowodować ich wzajemne wyniszczenie w 1 Hen $10,9 \mathrm{~b}^{60}$. Opis posłania Gabriela kończy się informacją związaną z prośba winowajców o długie życie, która nie będzie wysłuchana $(1 \mathrm{Hen} 10,10)$. Orędujący za cierpiącą ludz-

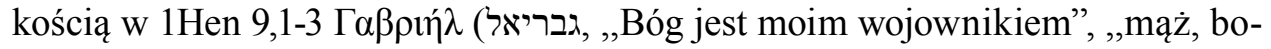
hater Boży”, „Bóg jest potężny”' ${ }^{61}$, w świetle 1Hen 10,9 manifestuje moc Boga i ukazuje Jego potęgę wobec gigantów $\left(\gamma \_\gamma \alpha \nu \tau \varepsilon \varsigma\right)^{62}$.

Czwarte posłanie (1Hen 10,11-16a) ${ }^{63}$ dotyczy kontynuacji misji Gabriela, która zostaje powierzona Michałowi ${ }^{64}$. Po tym, jak synowie upadłych Czuwających wzajemnie się wyniszczą (1Hen 10,12a), mają być oni związani aż do dnia sądu (1Hen 10,12b). Wcześniej Szemichaza i jego towarzysze zostaną pouczeni $(1$ Hen 10,11). Opis ich ostatecznego losu znajduje się w 1Hen 10,13-14, po którym następuje zamknięcie bloku 1Hen 10,1-16a informacją o zniszczeniu wszelkiego zła na ziemi (1Hen 10,15-16a). Wiadomość o Michale w 1Hen

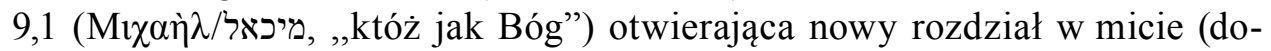
tyczący interwencji Najwyższego), sygnalizuje w 1Hen 10,11 zbliżający się moment rozwiązania problemu - ostateczne zwycięstwo nad złem, którego dokonuje sam Bóg ${ }^{65}$.

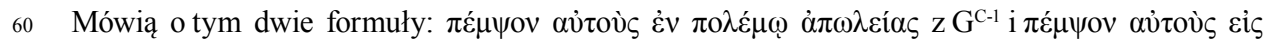

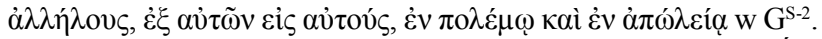

61 Księga Henocha mówi o Gabrielu jako jednym z siedmiu Świętych Czuwających aniołów, któremu podlega raj, węże i Cherubini w 1 Hen 20,7, oraz tym, który przewodniczy wszelkim mocom w 1Hen 40,9. Jego imię jest pierwszym imieniem archanioła w Biblii Hebrajskiej. W Księdze Daniela zostaje ukazany jako wyjaśniający wizję eschatologiczną (Dn 8,16) oraz z mądrością i zrozumieniem odpowiadający na modlitwę pokutną Daniela (Dn 9,21). Niektórzy postulują, że należy do grona siedmiu aniołów wymienionych w Apokalipsie (Ap 8,2). Zob. A.C. Myers, The Eerdmans Bible Dictionary (Grand Rapids, MI: Eerdmans 1987) 395; C.A. Newsom, "Gabriel (Angel)", The Anchor Yale Bible Dictionary (ed. D.N. Freedman) (New York: Doubleday 1992) II, 893. Por. misję Gabriela jako przekaziciela Bożego objawienia w Łk 1,5-38.

$62 \mathrm{~W} \mathrm{G}^{\mathrm{C}-1}$ jest obecne słowo $\mu \alpha \zeta \eta$ peol, będące transkrypcją aramejskiego terminu oznaczającego „bękartów”. Zob. F. Brown - S. Driver - C. Briggs, Hebrew and English Lexicon, 561. Natomiast $\gamma\left(\gamma \alpha \nu \tau \varepsilon \varsigma \mathrm{w} \mathrm{G}^{\mathrm{S}-2}\right.$ mieliby oznaczać nie tyle „mityczne stwory w postaci dzikich olbrzymich ludzi” czy „olbrzymów, wielkie, ogromne, mocarne, potężne stworzenia” (zob. Jurewicz, Stownik, 165), ale wojowników, których najbliższym odpowiednikiem zdaje się być słowo גברים - o tym samym rdzeniu, co imię גבריאל (por. m.in. Rdz 6,4; Joz 6,2; 8,3; 10,7; Sdz 6,12; 11,1; 1Sm 9,1; 2Sm 10,7; 2Krl 24,16). Na temat גברים i $\gamma(\gamma \alpha v \tau \varepsilon \varsigma$ w kontekście mezopotamskim zob. H. Drawnel, „The Mesopotamian Background of the Enochic Giants and Evil Spirits”, Dead Sea Discoveries 21 (2014) 14-38.

63 Grecki tekst 1Hen 10,11-16a występuje w $\mathrm{G}^{\mathrm{C}-1}$, natomiast część 1 Hen 10,11-14 jest obecna też w $\mathrm{G}^{\mathrm{S}}$.

64 Na temat związku między misją Gabriela i Michała w 1Hen 10,9-16a zob. Molenberg, „A Study of the Roles", 146. Duplikacje funkcji aniołów w 1Hen 10,1-16a zauważa również Nickelsburg (zob. Nickelsburg, „Apocalyptic and Myth”, 385).

65 Przywódca aniołów Mıðà̀ $\lambda$ w greckim tekście Księgi Henocha, poza 1Hen 9,1; 10,11, występuje jeszcze w 1Hen 20,5 jako czuwający nad narodem izraelskim oraz w 1Hen 24,6, gdzie jest jednym ze świętych i czcigodnych aniołów, stojącym na ich czele (por. jego rolę w Dn 10,13.21; 12,1). 


\subsection{Hen 9,1-3 jako odniesienie drugorzędne}

Wcześniejsze obserwacje dotyczące aniołów w 1Hen 9,1-3 ukazały, iż podejmują oni konkretne czynności, posiadają imiona oraz znajdując się w przestrzeni świętej nie pozostają obojętni na głos mieszkańców ziemi. Podobnego rodzaju informacje znajdują się również w początkowej części mitu (1Hen 6), gdzie jest mowa również o istotach niebiańskich. Są to jednak anioły, których działanie obiera inny kierunek niż w sytuacji przedstawionej w 1Hen 9,1-3.

Podobieństwo między 1Hen 9,1-3 i 1Hen 6 można rozumieć jako rodzaj paralelizmu, w którym te same idee i tematy zostają ukazane na zasadzie kontrastu. Nie są one pierwszoplanowym wątkiem w micie, jednakże ich zauważenie uzupełnia i ubogaca główny schemat narracji ${ }^{66}$. W tym kontekście wiersze 1 Hen 9,1-3 można rozumieć jako element drugorzędny (w sensie ścisłym: porównawczy) dla niektórych fragmentów rozdziału 1Hen 6.

Jednym $\mathrm{z}$ nich jest otwierający historię upadku Czuwających werset

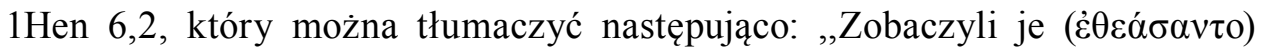

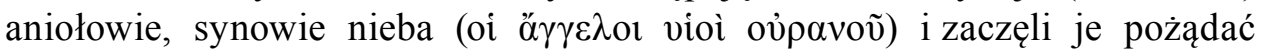

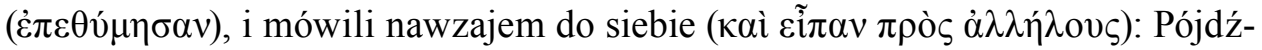
my $(\delta \varepsilon \tilde{v} \tau \varepsilon)$ wybierzmy sobie żony spośród ludzi i spłodzimy dla siebie dzieci”. Widać wyraźnie, iż w wersecie tym pojawia się kilka terminów obecnych również w 1Hen 9,1-3. Jednym z nich jest czasownik $\theta \varepsilon \alpha ́ o \mu \alpha ı$ (zob. §2.2a), który w 1Hen 9,1 dotyczy wrażliwości na cierpienie ludzkości, natomiast w 1Hen 6,2 jest również spojrzeniem ku ziemi, ale z innym zamiarem niż w 1Hen 9,1. Czynność patrzenia w 1 Hen 6,2 łączy się z pożądaniem kobiet $(\dot{\varepsilon} \pi \imath v \mu \varepsilon \dot{\varepsilon} \omega)$, na-

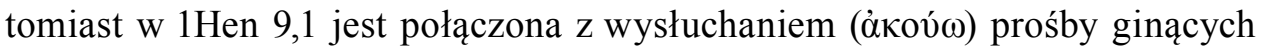
ludzi (zob. 1Hen 8,4$)^{67}$. Kolejnym wspólnym elementem jest zwrócenie się na-

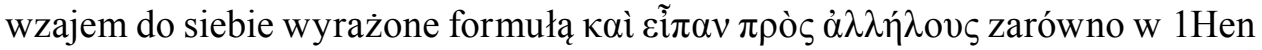
6,2 , jak i w 1 Hen 9,2 (w $\mathrm{G}^{\mathrm{C}-1}$, por. $\mathrm{G}^{\mathrm{S}-1}, \mathrm{G}^{\mathrm{S}-2}$ ). Podobnie jak w przypadku patrzenia aniołów, tutaj również różnica związana jest $\mathrm{z}$ intencją podjętej czynności. W sytuacji aniołów z rozdziału 1Hen 6 wzajemna rozmowa między nimi dotyczy spisku wobec ludzkości, którego ostatecznym skutkiem jest szerzące się zło opisane w 1 Hen 7,1b-8,4. Natomiast w 1 Hen 9,2 posłańcy rozmawiając ze sobą, podejmują naradę wobec ziemskiego dramatu, która owocuje modli-

W Nowym Testamencie występuje w Ap 12,7 - stoi na czele duchów niebieskich, które walczą z szatanem (por. Jud 9). Zob. Myers, The Eerdmans Bible Dictionary, 716; D.F. Watson, "Michael (Angel)", The Anchor Yale Bible Dictionary (ed. D.N. Freedman) (New York: Doubleday 1992) IV, 811.

66 Zob. Czerski, Metodologia, 149.

67 Należy zaznaczyć, iż czasownik $\pi \alpha \rho \alpha \kappa v ́ \pi \tau \omega \mathrm{w}$ 1Hen 9,1 (nieobecny w 1Hen 6) nadaje czynnościom aniołów wymiar pozytywny (por. Rdz 26,8; Sdz 5,28; $1 \mathrm{Krl} 6$,4; $1 \mathrm{Krn} 15,29 ; \operatorname{Prz} 7,6$; Mdr 14,23; 21,23; Łk 24,12; J 20,5.11; Jk 1,25; 1P 1,12). 
twą w 1 Hen 9,4-5 ${ }^{68}$. Trzecim elementem łączącym opisy aniołów w 1Hen 9,1-3 i 1 Hen 6,2 jest sposób, w jaki zostają przedstawieni. W 1Hen 6,2 są oni anio-

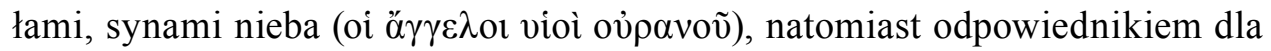
tego wyrażenia w 1Hen 9,3 jest nieobecne w tekście greckim określenie ,święci nieba" (קדישי שמיה) ${ }^{69}$. Wydaje się, że tekst 1Hen 6,2 mówi bardziej o naturze aniołów - o tym, iż są oni tymi, którzy należą do świata niebiańskiego. Z kolei adnotacja $\mathrm{z}$ wersetu 1 Hen 9,3 podkreśla dyspozycję aniołów do podjęcia modlitwy w miejscu świętym, sanktuarium niebieskim.

Innym wersetem będącym paralelą dla 1Hen 9,1-3 jest 1Hen 6,6: „Było zaś

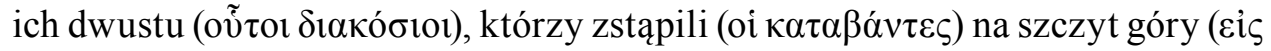

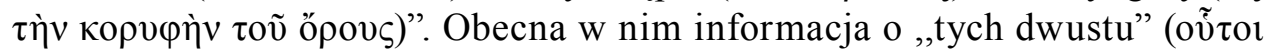

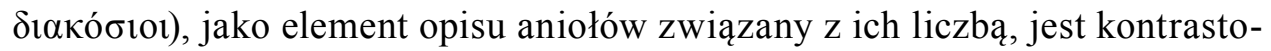

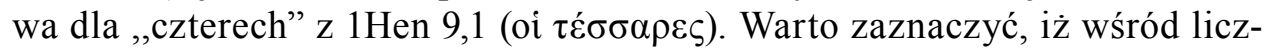
nych aniołów z 1 Hen 6,6 , znanych z imienia jest tylko kilku ich przywódców w 1 Hen $6,7^{70}$. Natomiast w 1 Hen 9,1 są przedstawieni wszyscy czterej anio-

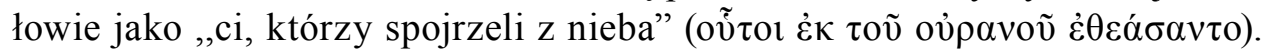
Drugą ważną informacją o aniołach jest ich czynność przemieszczania się.

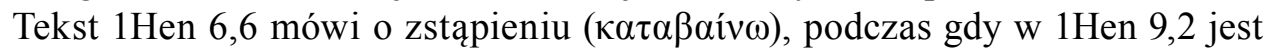

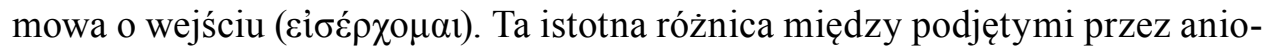
łów działaniami ukazuje kierunek ich intencji, które w sytuacji Czuwających z 1Hen 6,6 dotyczą sfery ziemskiej (zstępują na górę, tzn. wiążą się z tym, co ziemskie, tracąc kontakt $\mathrm{z}$ niebem), a w 1Hen 9,2 mówią o chęci zbliżenia się do Boga (wchodzą do świątyni, aby przynieść Bogu sprawy powierzone im przez zranioną ludzkość).

Trzecim motywem ukazującym kontrast między upadłymi w 1Hen 6 a świętymi aniołami w 1Hen 9,1-3 jest terminologia dotycząca ich miejsca w anielskiej hierarchii. W rozdziale 1 Hen 6 jest o tym mowa cztery razy: w 1Hen 6,3.7 trzy-

68 Wśród aktów lingwistycznych aniołów można wyróżnić różne rodzaje ich wypowiedzi: akty lokucji (treść ich wypowiedzi - narada i modlitwa w intencji ziemi w przypadku 1Hen 9,1-3 oraz spiskowanie przeciw ludzkości w 1 Hen 6); akty illokucji (cel/konsekwencje wypowiedzi - rozwiązanie problemu zagłady ziemi i podjęcie wstawiennictwa w 1Hen 9,1-3, współżycie z kobietami, spłodzenie gigantów i ich destrukcyjna działalność w przypadku 1Hen 6); akty perlokucji (chęć skłonienia innych postaci do konkretnego działania poprzez mówienie w przypadku 1Hen 9,1-3 osobą tą jest Najwyższy, który ma podjąć interwencję, odpowiedzieć na modlitwę aniołów, w 1 Hen 6 jest to zwrócenie się aniołów nawzajem do siebie oraz Szemichazy do innych aniołów Czuwających i sprowokowanie ich do wspólnego niszczycielskiego działania). Zob. H. Witczyk, „Wielowymiarowa re-kreacja postaci literackich”, Biblica et Patristica Thoruniensia $11 / 2(2018) 189$.

69 Jest ono zrekonstruowane przez Milika (zob. Milik, The Books of Enoch, 158, 171). Uwagi na temat tej rekonstrukcji znajdują się w: Nickelsburg, 1 Enoch 1. A Commentary, 203. Por. użycie tego wyrażenia w Dn 4,10.20.

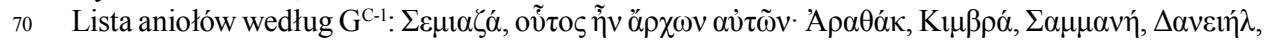

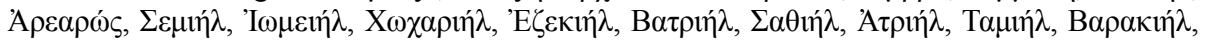

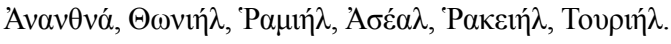


krotnie mówi się o przywódcach (ó $\rho \chi 0 v \tau \varepsilon \varsigma)^{71}$, z kolei w 1Hen 6,8 pojawiają się dowódcy (ả $\rho \chi \alpha i)$. Natomiast w 1Hen 9,1 obecni są wielcy archaniołowie ( $\mu \varepsilon \gamma \alpha \dot{\lambda} \lambda$ or $\grave{\alpha} \rho \chi \alpha ́ \gamma \gamma \varepsilon \lambda o \imath)^{72}$. Zdaje się, że różnice te - podobnie jak wcześniej - dotyczą postawy aniołów wobec ich funkcjonowania między niebem a ziemią. Czuwający z 1Hen 6, w świetle zauważonych w wersetach 1Hen 6,7-8 informacji, są osadzeni w kontekście militarnym i jawią się jako demoniczni wojownicy (por. 1Hen $7,2.4 ; 15,8.11)$. W przeciwieństwie do nich aniołowie w 1 Hen 9,1 podejmują się zadań wyznaczonych im przez Najwyższego i wykonują je zgodnie z instrukcją przekazaną im w 1Hen 10,1-16a.2073.

\subsection{Hen 9,1-3 jako moment przełomowy}

Tekst 1Hen 9,1-3 zajmuje ważne miejsce w strukturze 1Hen 6-11. Dotychczasowe analizy pokazały, iż wiersze te pozostają w relacji tematycznej do innych części mitu. Można powiedzieć, iż stanowią w nim summarium mówiące o problemach, które pojawiły się wcześniej (kontekst poprzedzający, mówiący o sytuacji na ziemi: 1Hen 6-8) i oczekują na rozwiązanie, które następuje po nim (kontekst następujący, opowiadający o świecie niebiańskim: 1Hen 9-11). Należy także zauważyć, iż w strukturze mitu znajduje zastosowanie schemat 1Hen 9,1-3 mówiący o dialogu między niebem a ziemią (zob. §2.4).

Od pierwszych zdań mitu (1Hen 6,1) akcja rozwija się i osiąga punkt dramatyczny w 1 Hen 8,4 . Po momencie przełomu, jaki następuje w 1Hen 9,1-3, zmierza ona w kierunku rozwiązania problemu, dochodząc do sytuacji końcowej w 1 Hen 11,1-2. Pierwszy etap narracji (komplikacja ${ }^{74}$ ) można przedstawić w następujących punktach:

71 W tym dwa razy słowo to dotyczy Szemichazy. Zob. 1Hen 6,2.7.

72 W Starym Testamencie termin $\alpha \rho \chi \alpha ́ \alpha \gamma \varepsilon \lambda o \varsigma$ jest nieznany. Dwukrotnie pojawia się w Nowym Testamencie: w odniesieniu do Michała w Jud 9 - jako wodza aniołów (por. też wyrażenie „wódz zastępów Jahwe" w Joz 5,14), oraz bez imienia anioła w 1Tes 4,16. Por. również podobne określenia w Dn 10,13; 12,1. W greckim tekście Księgi Henocha pojawi się jeszcze w 1 Hen $9,4\left(\mathrm{G}^{\mathrm{S}-2}\right)$ oraz 1Hen 20,7. Zob. Denis, Concordance grecque, 184; Myers, Eerdmans Bible Dictionary, 81.

73 Zaznaczony w niniejszym paragrafie termin $\delta \varepsilon \tilde{\tau} \tau \varepsilon$ („chodźmy”) w 1Hen 6,2 stanowi kontrast dla formuł posłania w rozdziale 1 Hen 10, których źródłem jest Pan (ó kv́pıs). Podobieństwo tematyczne dotyczące czynności posłania oraz różnica związana ze statusem nadawcy wykazują, iż czyn Szemichazy i jego towarzyszy jest bałwochwalstwem, gdyż anioł ten stawia siebie na miejscu Boga, przypisując sobie rolę przywódcy zastępów anielskich $\left(\mathrm{G}^{\mathrm{C}-1}: \sum \varepsilon \mu 1 \alpha \zeta \dot{\alpha}\right.$, oṽ̃os $\tilde{\eta} v$

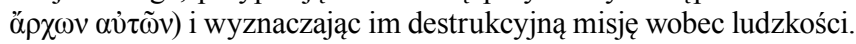

74 Komplikacja jest rozwojem akcji aż do momentu przełomowego (punktu zwrotnego), po którym następuje etap zwany rozwiązaniem (symetryczny do komplikacji, rozwiązanie trudności), które ukazuje szereg zmian w opowiadaniu spowodowanych przez moment przełomowy. Por. Węgrzyn, Analiza narracyjna, 30. 
1. Sytuacja początkowa mitu: Bunt aniołów (1Hen 6,1-7,1a)

2. Czyny upadłych Czuwających i ich skutki (1Hen 7,1b-8,4)

2.1. Działalność dydaktyczna Czuwających, cz. 1 (1Hen 7,1b)

2.2. Narodziny gigantów i ich destrukcyjna działalność (1Hen 7,2-5)

2.3. Cierpienie ludzkości, cz. 1 (1Hen 7,6)

2.4. Działalność dydaktyczna Czuwających, cz. 2 (1Hen 8,1-3)

2.5. Cierpienie ludzkości, cz. 2 (1Hen 8,4)

W 1Hen 9,1-3 pojawiają się nowi bohaterowie, zmienia się miejsce akcji, występuje odwołanie do wcześniejszej sytuacji i zapowiedź nowej formy dyskursu. Od 1Hen 9,4 rozpoczyna się etap drugi narracji 1Hen 6-11 (rozwiązanie komplikacji), który posiada następujące elementy:

1. Wstawiennictwo aniołów (1Hen 9,4-11)

2. Interwencja Boga (1Hen 10,1-22)

2.1. Posłanie aniołów (1Hen 10,1-16a)

2.2. Błogosławieństwo Boga, cz. 1 (1Hen 10,16b-19)

2.3. Nakaz usunięcia zła (1Hen 10,20)

2.4. Błogosławieństwo Boga, cz. 2 (1Hen 10,21-22)

3. Sytuacja końcowa mitu: Panowanie pokoju i prawdy (1Hen 11,1-2)

Powyższe punkty ukazują, iż opowiadanie 1Hen 6-11 posiada układ symetryczny, gdzie etap rozwiązania problemu (1Hen 9,4-11,2) odpowiada wcześniejszej komplikacji (1Hen 6,1-8,4). Poza tym przedstawia on, w jaki sposób zdarzenia obecne w 1Hen 9,1-3 wpływają na dalszy ciąg akcji, zachowania i losy bohaterów oraz zmiany zachodzące w świecie opowiadania. Pierwsza część mitu zdominowana jest przez działalność Czuwających (1Hen 7,1b; 8,1-3) i ich potomstwa (1Hen 7,2-5). Dwukrotnie narrację przerywa informacja o reakcji mieszkańców ziemi, którzy skarżą się na nieprawych $(1$ Hen 7,6$)$ oraz ginąc, wołają do nieba $\left(1 \mathrm{Hen} 8\right.$,4). Zdarzenia mają miejsce na ziemi, która cierpi ${ }^{75}$. W części drugiej akcja rozgrywa się w przestrzeni niebiańskiej (1Hen 9,4-11), a inicjatywę przejmuje Bóg (1Hen 10-11), który posyła czterech aniołów (1Hen 10,1-16a.20). Relacja o tym jest paralelna do opisu czynów upadłych Czuwających (1Hen 7,1b; 8,1-3) oraz gigantów (1Hen 7,2-5), natomiast słowa błogosławieństwa (1Hen

75 Kontekst zdecydowanie mówi o ziemi jako miejscu akcji w 1Hen 6-8. Warto jednak zaznaczyć, iż termin $\gamma \tilde{\eta}$ pojawia się częściej w drugiej części mitu - 1Hen 9-11 (według $\mathrm{G}^{\mathrm{C}-1}: 2$ razy w 1 Hen 9,1-3 i 16 razy w 9,4-11,2; jeden raz w 1 Hen $6-8$ ), gdzie opisane zdarzenia rozgrywają się w niebie. Natomiast słowo oủpavó występuje systematycznie w obu częściach mitu (według $\mathrm{G}^{\mathrm{C}-1}: 2$ razy w 1 Hen 9,1-3 i 2 razy w 1 Hen $6-8$; 3 razy w 1 Hen 9,4-11,2). 
10,16b-19.21-22) zdają się odpowiadać rozpaczliwemu wołaniu ludzkości (1Hen $7,6 ; 8,4)$.

Taki przebieg zdarzeń w micie 1Hen 6-11 ukazuje proces, jaki zachodzi między sytuacją początkową 1Hen 6,1-7,1a a sceną końcową 1Hen 11,1-2, w którym wersety 1Hen 9,1-3 stanowią niezbędny moment przejścia od przemocy, bezprawia, bezbożności i cierpienia zaistniałych na ziemi do nieba, które oczyszcza ziemię, błogosławi ją i wstawia się za nią.

\section{Podsumowanie}

Przedstawione w niniejszym artykule analizy, oparte na podejściu synchronicznym, uzupełniają koncepcję Hansona, który jako jedyny z przywołanych we wstępie autorów, osadził 1Hen 9,1-3 w szerszym kontekście (zob. §1). Potwierdzają one również pozostałe opinie (Nickelsburg, Drawnel, Molenberg), w których kontekst bliższy badanego przez nas tekstu 1Hen 9,1-3 - historia Asaela 1Hen 8,1-3 zakończona skargą ludzkości 1 Hen 8,4 oraz treść modlitwy wstawienniczej aniołów 1Hen 9,4-11 - pokazuje, że 1Hen 9,1-3 kontynuuje temat cierpiącej ludzkości z 1Hen 8,4 oraz wprowadza do 1Hen 9,4-11. Odczytanie wersetów 1Hen 9,1-3 w świetle całego mitu ukazało ponadto kilka niedostrzeżonych dotąd funkcji tego krótkiego epizodu w strukturze 1Hen 6-11. Tekst 1Hen 9,1-3 jako element pierwszorzędny w strukturze mitu przedstawia sens logiczny zdarzeń mających miejsce w rozdziale następnym - opisie posłannictwa aniołów 1Hen 10,1-16a. Taka funkcja 1Hen 9,1-3 okazuje się bardzo pomocna w wytłumaczeniu roli archaniołów w micie (oraz w 1Hen), których postawa ma kluczowe znaczenie dla dalszego biegu zdarzeń. Słownictwo i tematyka 1 Hen 9,1-3 pozwala tekst ten zestawić z wersetami 1Hen 6,2-3.6-8 przynależącymi do sceny początkowej mitu. Powiązanie to umieszcza 1Hen 9,1-3 w ramach tekstów obrazujących charakterystyczną dla literatury apokaliptycznej ideę dualizmu w świecie bytów nadprzyrodzonych oraz konfliktu pomiędzy ludzkością a złymi duchami (ideologiczno-pragmatyczna funkcja tekstu). Perykopa 1Hen 9,1-3 dzieli też narrację mitu na dwie główne części, opisując moment przejścia między sytuacją problemową (1Hen 6,1-8,4) i jej rozwiązaniem (1Hen 9,4-11,2). Podział taki wprowadza propozycję struktury 1 Hen $6-11$, która różni się od dotychczas proponowanych rozwiązań ${ }^{76}$.

76 Wpisuje się ona w problematykę dotyczącą złożoności redakcyjnej Księgi Czuwających. Zob. Charles, The Book of Enoch, 1-4. Kilka opinii na ten temat przywołuje Iwański (zob. Iwański, Wstawiennictwo aniołów, 60). 


\section{Bibliografia}

Abegg, M.G., The Dead Sea Scrolls Concordance. Vol. 1: The Non-Biblical Texts from Qumran (Leiden: Brill 2003) II.

Argall, R.A., 1 Enoch and Sirach. A Comparative Literary and Conceptual Analysis of the Themes of Revelation, Creation and Judgment (Society of Biblical Literature. Early Judaism and Its Literature 8; Atlanta, GA: Scholars Press 1995).

Balz, H. - Schneider, G., Exegetical Dictionary of the New Testament (Grand Rapids, MI: Eerdmans 1990) I.

Black, M., Apocalypsis Henochi Graece (Pseudepigrapha Veteris Testamenti Graece 3; Leiden: Brill 1970).

- - The Book of Enoch or I Enoch. A New English Edition with Commentary and Textual Notes (Studia in Veteris Testamenti Pseudepigrapha 7; Leiden: Brill 1985).

Brown, F. - Driver, S. - Briggs, C., The Brown-Driver-Briggs Hebrew and English Lexicon: With an Appendix Containing the Biblical Aramaic (Oxford: Clarendon Press 1907).

Charles, R.H., The Book of Enoch or 1 Enoch. Translated from the Editor's Ethiopic Text (Oxford, MS: Oxford University Press 1912; repr. Eugene, OR: Wipf and Stock 2011).

- - The Ethiopic Version of the Book of Enoch (Oxford: Clarendon Press, 1906; repr. Collingwood, Vic.: Trieste 2017).

Cook, E.M., Dictionary of Qumran Aramaic (Winona Lake, IN: Eisenbrauns 2015).

Czerski, J., Metodologia Nowego Testamentu (Opolska Biblioteka Teologiczna 26; Opole: RW UO 2012).

Danker, F.W., A Greek-English Lexicon of the New Testament and other Early Christian Literature (Chicago, IL: The University of Chicago Press 2000).

Davidson, M.J., Angels at Qumran. A Comparative Study of 1 Enoch 1-36, 72-108 and Sectarian Writings from Qumran (Journal for the Study of the Pseudepigrapha. Supplement Series 11; Sheffield: A\&C Black 1992).

Denis, A.M., Concordance grecque des Pseudépigraphes d'Ancien Testament (Louvain: Peeters 1987).

Drawnel, H., „1 Enoch 6-11 Interpreted in the Light of Mesopotamian Incantation Literature”, Enoch and the Synoptic Gospels. Reminiscences, Allusions, Intertextuality (ed. L.T. Stuckenbruck - G. Boccaccini) (Society of Biblical Literature Early Judaism and Its Literature 44; Atlanta, GA: SBL Press 2016) 245-284.

- - Qumran Cave 4: The Aramaic Books of Enoch (Oxford: Oxford University Press [w druku]).

- - , ,The Mesopotamian Background of the Enochic Giants and Evil Spirits”, Dead Sea Discoveries 21 (2014) 14-38.

——, „Ukaranie Asaela (1 Hen. 10,4-8) w kontekście mezopotamskiej literatury zwalczającej czarną magię", Biblical Annals 3 (2013) 285-307.

——, „Zawodowa wiedza Asaela (1 Hen. 8,1) i jej relacja do starożytnej Mezopotamii”, Biblical Annals 3 (2013) 47-66.

Hanson, P.D., „Rebellion in Heaven, Azazel, and Euhemeristic Heroes in 1 Enoch 6-11”, Journal of Biblical Literature 96 (1977) 195-233.

Iwański, D., „Mieszkanie Boga w niebie według Księgi Czuwających (1 Henoch 14,8-23)”, Collectanea Theologica 79/2 (2009) 101-112.

——, Wstawiennictwo aniołów w Księdze Henocha (1Hen) (Scripta Theologica Thoruniensia 15; Toruń: Wydawnictwo Naukowe UMK 2011).

Joüon, P. - Muraoka, T., A Grammar of Biblical Hebrew (Subsidia Biblica 14; Roma: Editrice Pontificio Instituto Biblico 1991) II.

Jurewicz, O., Stownik grecko-polski (Warszawa: Wydawnictwo Naukowe SUB LUPA 2015). 
Koehler, L. - Baumgartner, W., Wielki stownik hebrajsko-polski i aramejsko-polski Starego Testamentu (Warszawa: Vocatio 2013) I.

Kvanvig, H.S., „,The Watcher Story and Genesis. Intertextual Reading”, Scandinavian Journal of the Old Testament 18/2 (2008) 163-183.

Milik, J.T, The Books of Enoch: Aramaic Fragments of Qumran Cave 4 (Oxford: Clarendon Press 1976).

Molenberg, C., „A Study of the Roles of Shemihaza and Asael in I Enoch 6-11”, Journal of Jewish Studies 35 (1984) 136-146.

Mosshammer, A.A., Georgii Sincelli Ecloga Chronographica (Leipzig: Teubner Verlagsgesellschaft 1984).

Muraoka, T., A Grammar of Qumran Aramaic (Ancient Near Eastern Studies 38; Leuven: Peeters 2011).

——, A Greek-English Lexicon of the Septuagint (Louvain: Peeters 2009).

-—, A Greek-Hebrew/Aramaic Two-way Index to the Septuagint (Louvain: Peeters 2010).

Myers, A.C., The Eerdmans Bible Dictionary (Grand Rapids, MI: Eerdmans 1987).

Newman, B.M., Greek-English Dictionary of the New Testament (Stuttgart: Deutsche Bibelgesellschaft 1993).

Newsom, C.A., "Gabriel (Angel)", The Anchor Yale Bible Dictionary (ed. D.N. Freedman) (New York: Doubleday 1992) II, 893.

——, "Uriel (Angel)", The Anchor Yale Bible Dictionary (ed. D.N. Freedman) (New York: Doubleday 1992) VI, 769.

Nickelsburg, G.W.E., 1 Enoch 1. A Commentary of the Book of 1 Enoch, Chapters 1-36; 81-108 (Hermeneia; Minneapolis, MN: Fortress Press 2001).

-_, ,Apocalyptic and Myth in 1 Enoch 6-11”, Journal of Biblical Literature 96/3 (1977) 383-405.

Rzepka, B., „Pytanie o właściwą metodologię analizy narracyjnej”, Biblica et Patristica Thoruniensia 11/2 (2018) 147-158.

Schmidt, F.W, "Raphael (Angel)", The Anchor Yale Bible Dictionary (ed. D.N. Freedman) (New York: Doubleday 1992) V, 621.

Sisson, J.P., „Intercession and the Denial of Peace in 1 Enoch 12-16”, Hebrew Annual Review 11 (1987) 371-386.

Stuckenbruck, L.T., „Theological Anthropology and the Enochic Book of Watchers (1 En. 6-11)”, Dust of the Ground and Breath of Life (Gen 2:7). The Problem of a Dualistic Anthropology in Early Judaism and Christianity (ed. J. van Ruiten - G. van Kooten) (Themes in Biblical Narrative 20; Leiden: Brill 2016) 16-35.

Szymik, S., Wspótczesne modele egzegezy biblijnej (Lublin: Wydawnictwo KUL 2013).

Watson, D.F., "Michael (Angel)", The Anchor Yale Bible Dictionary (ed. D.N. Freedman) (New York: Doubleday 1992) IV, 811.

Węgrzyn, A., Postawy wobec Jezusa ofiarujacego miłość. Analiza narracyjna (Łk 7,36-50) (Studia Biblica Lublinensia 16; Lublin: Wydawnictwo KUL 2016).

Witczyk, H., „Wielowymiarowa re-kreacja postaci literackich”, Biblica et Patristica Thoruniensia $11 / 2(2018)$ 177-195. 
